University of Rhode Island

DigitalCommons@URI

Open Access Master's Theses

1958

\title{
American Policy in the Kashmir-Jammu Dispute Before the United Nations 1948-1957
}

Ronald Leach Wrigley

University of Rhode Island

Follow this and additional works at: https://digitalcommons.uri.edu/theses

\section{Recommended Citation}

Wrigley, Ronald Leach, "American Policy in the Kashmir-Jammu Dispute Before the United Nations 1948-1957" (1958). Open Access Master's Theses. Paper 1785.

https://digitalcommons.uri.edu/theses/1785

This Thesis is brought to you for free and open access by DigitalCommons@URI. It has been accepted for inclusion in Open Access Master's Theses by an authorized administrator of DigitalCommons@URI. For more information, please contact digitalcommons-group@uri.edu. 


\section{DS 485 K2 \\ W' 7}

\section{AUERI CAY POLICY}

IN THET KASHMIR-JAMMV

DISPUTE BEEORE THE UHITED NATIONS,

$1948-1957$

BI

RONAED LEACH WRIGLEY

A THLSIS SUBMITTED IN PAFTIAL FULFILLMRM OF THE

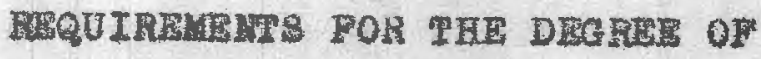

MASTER OF ARTS

IX

POLITICAL SCIENCE

WIVIMSITX OF RHODE ISLAMD

1958 
ABSTRACT

The Indi-Pak1stan dispute over the state of Jammu and Kashmir has been before the Securlty Councll of the United Nations intermittently for some ten years. In all the attempts at settlement the only accomplishment of this body has been to effect a cease-fire agreement between the two disputants. The miter's objective in this paper is to investigate American polley in the dispute before the United Nations in an effort to discover the offiolal position taken by the United States government.

In ming a study of this type it was necesary for the writer to investigate the primary records of the United Nations General Assembly and the Security Council. Greater emphasis was placed upon the verbatim records of the Socurity Council, for it was in this organ that American policy was most ovident. The main body of the thesis has been developed from these records. Other primery records oxamined vere the State Dopartment Bulletins which oxpressed broad American policy in regard to South Asia and 1ts effect on the Kashmir 1ssue. The New York Times proved an invaluable source of information for statements and actions taken by the United Stater and the Security Council which were not yet published in the offlolal records of the U. N. The writer was able to obtain valuable primary and secondary 
material from the embasies of India and Pakiatan in Washington, D. C. These wero examined in order to ascertain the offleil polley of the two disputants. Secondery source materiel was found in the roports and bullotins of the Forelgn Polley Association and verlous books. These were examined for interpretation and application of fact obtained from the primary sources.

The results of the study seem to indicate that the United States continuelly urged the two partles to use peaceful means of settlement and to abstain from any use of force. This was a polley consistent with Chapter I, Artiele 2, Section 3, of the United Nations Charter. Second, Washington placed grent emphasis upon a plobiscite in Kashmir under Unfted Nations auplces. The pleblecite alone would determine the final accession of the atate to elther India or Paklatan. Thls prinelple of selfdetermination has been a traditional polley of the Unlted States.

Third, the United States denled the validity of the orlginal accession instrament igned by the Maharaja of Kashmir and the Indian government. Furthermore, the State Departmont viewed Indian control over Kashir as temporary. Fourth, the Unlted States refused to condemn Pakiatan as an agressor in Kashmir. This was charge that India hed sought from the Security Counc1l since the introduction of the dispute in 1948 .

F1fth, wasington sponsored jolntiy with other Counc11 
members nine resolutions seeking to bring the parties to sottlement. Both alsputants for various reasons were unable to aceopt the recommendations and suggestions made in the retolutions.

Sixth, the United States has mintalned that military aid to Pakiatan has not changed the Kashmir issue, nor alterod the facts of the dendlock. Later milltary pacts, such as the SRAFO and Begded treaties between the United States and Paklstun, are conslstent with the Charter of the United Nations. 


\section{A CKWOULEDOMERI}

It 18 ith grov appreatation that the writer thanks Dr.. Danlel H. Thomas, Find of the Department of Hlatory and Politien selence, and Professor Duv1d D. Warren for thelr valuable azgestions and critlolsms. The writer is greatly Indebted to Professor F. P. Alion; Univerity Librarian, and mombers of his sterf for thel helpful and courteous asatsance in 1 peating materials. The witer also wishes to thank the taff of the Indian and Pak1stan1 Embassies In waington, D. C., top thelr generous contribution of secondery and priwary source materials. 
TABLE OF CONFEMP

Page

ABSTRACT

Chapter

I. IMRODUCTION ...............

II. THE HOSTILITIES AND THE CEASE-FIRE

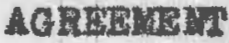

The United Netions Intervenes

Informal Discussions on Kashmir

A Three-Man Commission on Kashmir

Indian Pollcy in Kashmir

Waehington's View That Indian Control over Kashmir Was Temporary

The United States Proposes Second Commisalon for Indian-Pairistan Bispute

American Delegate Comments on Powers of UNCIP and Interpretation of Pacifio

Settloment

The Cose-Fixe

Amerion Polloy in the Firat Yoar of the Kashmir Doathiock

III. NEW MEREODS OF SOLUTION ........

India Suggets Arbitration on Agreod

\section{Is sues}

DHCIP Reporte to the Security Counoll

Washington Suggests Appointwent of a

0. I. Reprosentative to Replace

UNCIP

Washington Hotes Iraprovement in Indian-

Paklstian Relations

S1r Oven Dixon's F1rst Report to the

Security Coune11

American Delegate Expresses Apprehension

over Const1 tuent Asaembly in Kashmir

The Second 0 . N. Representative

New Delh1 Objects to the Resolution

Conetituent Assembly Again Annoy: the

State Department

Tho Second Graham litsaton 
Further Mediation Erforts

Diacussion in the General Assembly

A Fifth Anglo-imerican Resolution Sends Graham to the Sub-continent

American Polley during the Perlod 19501952

IV. MILITARY AID TO PARISTAN ......... 4 .

The " Northem Tier" Defense. System St1pulations under Military Ald Program

U. S. - Indian Relations

Economic Ald to India.

Reglonal Pacts

SEATO a Viemed by India

Karachi Vlews. Kashnir Deadlook w1th Inpatience

V. RECELH DEVELOPUEMTS ............

Approhensions over Constituent Assembiy

security Counc1I Resolution Reaffirms

Its stand on a Plebiacite

New Delhi Answers the Seourity Counoll

The Jarring Hision

Election in. Indian-Held Kashmir

The Jarring Report

Habington and Karachl Continu Thelp

Demands for Plebiscite

The Resolution of December 1957

Pak1stan Sooks Support Through Its

Homborahip in the Bagdad Pact

vI. CONCLUSIOHS ...............

U. S. Polloy toward the Accession

Instrument

Peaceful lethods as the Firat Sey to

Settlement

The Second Key to 'Settlement

Charges of Aggreasion

Anorien Polleles Were Not Noutrallot

The Effect of Broad $\nabla$. S. Polley upon

the Kesheir Is sue

Prospects for the Future 


\section{CHA PIES I}

\section{INT RODUCTIO}

On Auguet 15. 1947, Great Britain witharew from the sub-continent of India. Britlah India was to be partitioned Into two major states - India and Pakiatan - with the future or some 565 princels atates to be determined by the rulers of the states themselves. ${ }^{1}$ With reference to the constitutional consequenoes of partition for the Indian princely states, the Indian Independence Act of JuIy 18, 1947 stated:

As from the appolnted duy (August 15, 1947). . . the suzerainty of Fil siaty over the Indian States lapses, and w th It, 11 treaties and agreements in force at the date of the pasalng of this Aet... all oblightions of His litejety exlating at that date towards Indian states or the Fulers thereof, and all powers, Nights, athority or jurlediction exercisable by His Majeaty at that date in or in relation to Indian States.

Frow atrietly legal point of view, both Findu and Moslow political leaders agreed that this provision granted full froedom of action to the prineely states, 1.e., to accede to elther India or Pakistan or to remain as Independent states. The general ascimption was that the Moslem states

1MI chael Brecher, Struggle for Kaahm1r (New York: oxford University Preas; 1953). p. 19.

2Ib1d., p. 19. Brocher has reproduced this from the Government of India's, White Paper on Indien States (New DeIh1, 1950), p. 153. 
would accede to Paklstan and the Hindu states to India. Since Kasholr had not jolned with elther dominion, it became technically an independent tate. ${ }^{2}$ Two other rulers, those of Junagadh and Hyderabad also chose to join neither dominion, and their subjects would pag dearly for thelr rulers' in-. declsion. In September, 1947, the Moslem mulex of Jundgadh. acceded to Pakistan, but the Indian army entered the state and asured the 700,000 Hindus thet 1 would protect their rights and future. They roted for India. Similar events occurred when the Hollen ruler of Hyderabad tried to postpone inderinttely any deciaion coneerning the future status of his predominently Hindu state, and in September, 1948, the country became a part of India. The fate of Kaghmir was not as simple as thet of the prevlous two states. Religtous strife between the two peoples of the subcontinent was al reedy ragling uncheoked. Leaders of the Muslim League and the filnalu Congress hurled cherges back and forth. Rlote puchod thretenlng proportions in several reglons, partieulerly in the Punjab, bordering on Iashmir. Thousands of people vere k1lled, millions driven from their homes, and countless villagea were burned to the ground. The long awalted dey of Independenoe wo horalded with death, destruction and anguish.

The two newly otablished goverment were unable to

I Hichael Brecher, Struggle for Kahmir (Now York: Oxford Univera1ty Press, 1953), p. 20. 
cope wth the situation. Diblaced persons fleelng from Hindu to Hoslem territorles and viee-versa reached a staggering number. After these masive population movements were over, Hindu Indla still had 40,000,000 Muslims vithin 1ts borders, and Hoslem Pakistan was left with over 12,000,000 Hidus.

The rellgious frensy that swept the area affected Kachmir as well as the otber princely states. In the spring of 1947 the Hndu Whareje brutally suppressed a "no tax axpalgn wheh the Moslom population had tried to enrry on. Followers of the Croseint from the Punjab and other districta entered the country to ald their Muslim brothers. The Mahareja, fearling ths own position, sought and recelved assistance frow Sikh ind Hinat otronts from aroas outalde Kashmir. 1

Waharaje Har1 Singh of Kashnir was repeatediy advised by Loxd Mountbatten to ascertaln the $\mathbf{1 1 1}$ of $\mathrm{hls}$ peoplo and to join one of the dominions. He disregarded this advice. Prossure within the ste continued to mount as refugees poured Into the area from the Punjab bxinging with them the tensions and fears of bloodched end death. Many Muslims of Kammir fell before the rifles of the Maharaja's troopa. Moanthl10, in Pakistan the tribesmen called for lohad or holy war to arenge the death of their rellglous brethren. Aroused by the atrocities committed by the ruler's troops, 


$$
\text { 4. }
$$

the Afrld and Mahoud warplors erossed the Kashmir frontier and swept 1nto the Jheluw river valiej, eompletely cruahing 11 oppostition. 1 Vnfortunately, the Invasion exceeded 1 ts bounds and ended in the raping, looting, and plileging of Hindus Muslims alke. Aocording to Robert Trumbul1, He: Yoxix Pimes correspondent, the atrocities probably reached their peak at Baramulle whore on estimated

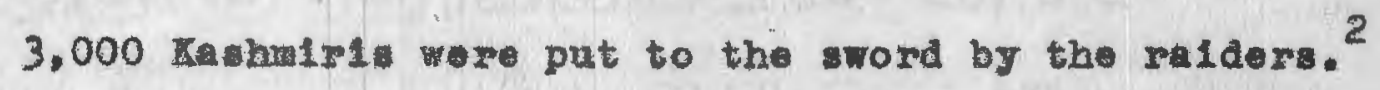
On Oetober 26, 1947, the Maharaja of Kashmir Informed the Indian govemaent at Dolni that he had declded to foin the Indian Dorinion and at the same time he askad for milltary ald to halt the Invasion of his state by the tribesmen. On the followlag day Indla ceepted the acession of the Jammu and Kashalr state to their dominion and sent Indian troops inte Kasbuir. 3

Paklstan's only wove here was to invito Indian lederg to Lahore for a discustion of the stuation. A conference was held on November 1 at which both the Governor-General were present. Whey were unable to arrive at any lasting agreements. Howevor, All Jinnah, GovernorGeneral of Paklstan did present a three-polnt proposal Involving a cense-fire, Itharawal of all allen troops,

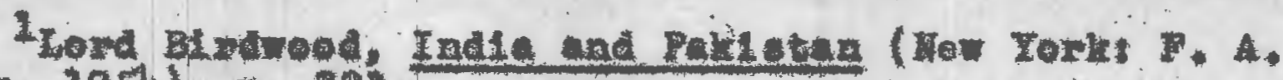
Preeger, 1954), p. 223 .

21rovember 10, 1947, p. 24.

${ }^{3}$ Lord Bindrood, India and Bakistan (New Fork: 5. Preeger, 1954), P, 224. 


$$
-5
$$

and a pleblselte under jolnt control of India and Paklstan. Mountbetten rojected Jinnah's proposals, and auggestod that the pleblelte bo administered by the united Wations, but Jinnah diagreod th this, wnintiming that the Covernors-deneral should organine it jolntly. Hevertho16ss, on November 16 Llaquat All Than, Prime Haister of Paklatan, asked that the United fiatlons be approabled for a vettiement of the alspute. At f1rst the Indian government

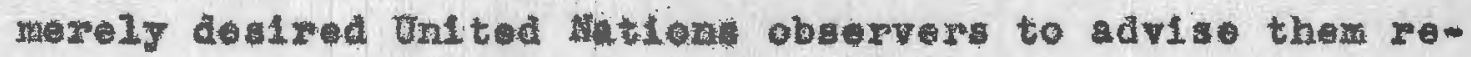
garalng a plobsolto, bat fow weoks later Delhi officialy requested the Unltod Haflons to intervene in the Kashrir conf210t. 2

${ }^{1}$ Joser Koxbel, Danger in Kashmir (Princeton, How Jerseg: Prineton पaiversity Press, 1954), p. 88.

$$
\text { Irte., p. } 90 .
$$




\section{TH HOSTILITIBS \\ AND THE CEASE-FIRE AGREEMENT}

The United Nations Intervenes

On January 1, 1948, the Government of India transmitted a letter to the President of the Security Counc1l aring that body to Intervene in the Kashmix dispute between 1ts country and Pakistan. Indla sectrienly requested that the Counell ask the Government of Paklstan to prevent its nationals from partielpting or asisting in the invasion of Kashmir. India further roquested that Pakistan refuse to the Invaders access to and use of her territory for any hostillties against Kashmir, and that Paklstan halt the movement of supplies or other materila to the invaders ${ }^{2}$ At a moting of the security councli on Janungy 6 the Kashmir Issue was placed on the genda, Initiating a diacuasion which was to last intermittentig for ton years. The President of the Counc11, Fernand van Langenhove of Belgium, after asking for objections and flnding none, conoluded that the councli agreed to Invite Paklstan and India

IUnited Nat1ons, Security Counell, offleial Records: 3rd Ir... Supplement for November 1948, Herearter rererred to as U., H.: S. C., Off. Ree. 
to partiolpate in the discussions.

Not1ng that both the Indian and Pakistanl delegates had sufficlently prepared theif brief on the Kashmir 1ssue, President van Langenhove scheduled a dscussion on January 15 at Lake Success, wew York. The flrst to peak was Gopalaawani Ayjangar of India, who rostated the original requeat of his government and indicated to the Coune11 that his goromatent had "at no time put the alightost presway on the state to acede to the Indian Dominion,

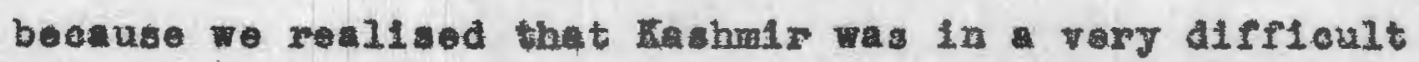
position." ${ }^{2}$ He also declared that India preparing to negotiate otandst111 agreament with Kashmir, an agreoment which Paklatan had already accepted in telogram to the Kaabmir government ome time ariler. 3

The flrst offleial pollog of the United states was given on the same day by the Amertcan pepresentative, warren Austin. Ho stated thit the Kaskmir 1s sue was of utmost Importance, but that "no intemperate action should be taken

I0.,., s. 0., Off. Rec., 3rd Ir., 226th Moting, 6 January 1948, No. $1-35$, p. 5 .

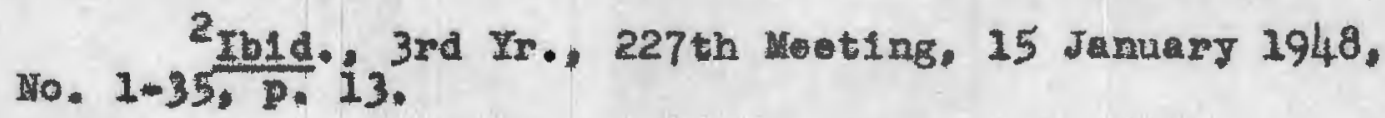

3rho than Ja of Kashrix, Harl Singh realised the necessity of reaching ome understanding with the dominions of India and Pakisten. He notifled both governments of his willingress to negotiate a standst111 Agreement. On August 15. 1947, he signed such an greement ith Pakistan giving the latter complete operation of postal and tolegraph faclities. Pakistan was also charged with the responalbility of supplying food and other necessities. Indie nolther accopted nor rejeoted the Maharaja's request. 
by the Security Council either in polnt of time or in point of substance." 1 Wahingten folt that 11 ldes of the greation ahould bo thorengly alred before the councli acted on any resolutions in regher to the iswue. On Jenuary 16, 1948, the Pakistan case was prosented by Sir Mohnmed Zafmulle Khan, who argued that Moslems in Kashmir were beling murdered and butchered by the Kaharaja's troope, and that Pakitan could not stand $1 \mathrm{dly}$ by while these killings were taking place. He proclalmed that his government was astonishod to learn that Kashir was seoking "assistance" from an outside power. ${ }^{2}$ continulng his discussion on the following day, Khan suggested that the tribesmen withdrat from Kashir, and at the same time have the Indian troops remorod to areas outalde the state. H1. furber commendations were to eatablish coase-rire, and then the Governors-General of Pak1stan and India would be given complete and rull power to restore the pece. Following this aotion, Khan wanted the Governors-Ceneral to undertake full administration of tho Jamma and Kashmir state and rrange a plobisclte wihout delay. ${ }^{3}$

1. H. 8. C., Orf. Foc., 3rd Yr., 227th Meeting, 15 January 1948 , No. $1-35, \mathrm{p} .34$.

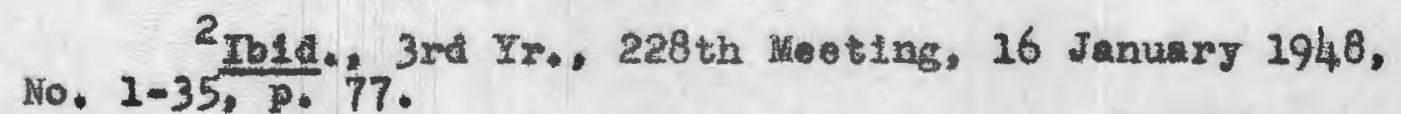

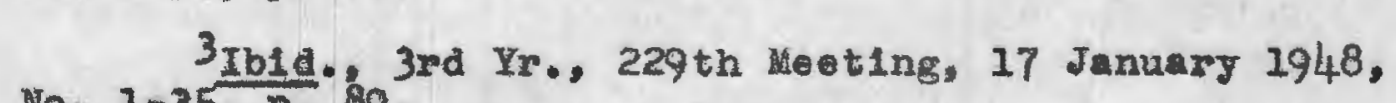
No. $1-35.99$. 
Informal Discusstons on Kashmir

After hoaring the case as presented by the Indian and Pakiatanl Fepresentatives, the Unted Kingdom reomended several possible methode of eolution. Pisst, the Counell would enll upon the goverments of both oountrles to refrain from. Issuling any statements that would aggravato the situation, and then the two gevemmonte would soek solution by direct negotiations. Meanwile, both countwies would 1nforth the Counell on any meters that could poesibly ehange the situation.

Tho American delogition upported the proponals made by the United Ingdoin and exphatically endored the recomendations that India and Pakiatan try to reach an agresment on their problom by alrect negotiation. Wahington advised that the Counell recess for several days Iu order to give the paxtios sufflefont time to consider the mater. 1

Ayganger of Indi and Khan of Paki tan both welcomed tho Unfted Kingdom proposals. The Indian delogate 1 gniflonatiy praised these draft resolution as giving India and Pakistan an opportunity to arrive at solution which would be aceptable to both parties. ${ }^{2}$

Thu negotiation entered that type of informal

1. 17 January 1948 , No. $1-35,9.126$.

Ibld., pp. 126-27. 
conversations wich wore dosigned, in the plrit of Chapter VI of the United atlons Charter, to seok settlement by direct attempts of the parties in alspute, before the Secur1ty Counc1l would have to intervene and make recommendations.

\section{A Throe-han Commission on Kashmir}

On January 20,1948 , a a result of these informal conversations, resolution was passed in the council establishing United Nations commasion to investigate the facts and exerelse modiatory influence. Washington supported this resolution, noting that both perties wanted the dispute settled by peaceful means and not by the intervention of armed force. The American position stressed the point that pleblscite should bo held under the supervision of the United Nations. This rould ensure complete impartiality on the part of the pleb1scite adminlatrators and would permit the poople of Jaumu and Kashmir to exercise their vote in a free and democratic manner. 1

Unfortunately, the first three-man commission established by the Council was not dispatched to the subcontinent. The resolution which created the mediatory body was highly wodest one. It made no wention of the

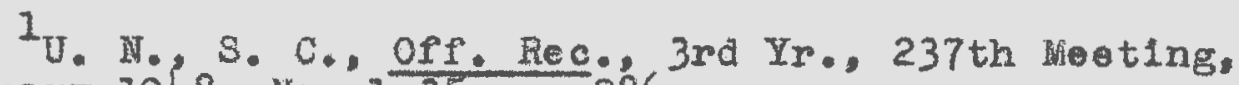
29 Januery 1948 , No. 1-35, p. 286. 
wtharawal of elther the tribeswen or the Indian army, nor did it incorporate the American demand for plebisolte. The comission falled to ccomplish any lasting agreoments between the two disputants.

\section{Indian Polfcy in Kashmir}

The Indian position from the very beginning was that India was in fact and in law the legal sovereign of the Jaminu and Kasmir stata. The faharaja had legally accoded lis princoly state to the Indian Union. Pakisten military forces had Invaded Indian territory by going lato Kashmir and the Council, according to Hew Delht, must condem paristan as an aggressor. No possible settlement would bo considored by India until the Yakistari eivilians (tribesmen) and miltary porsonnel were withdram frow the state. The Indian government would not consider anj pleblscite unt1l those forces were withdrawn.

Washington's V1ew That Indian Control over Karhmir Was Temporary

Indian control over Rashmir was only temporary as soen by warren Austin, American delegato to the Security Council. A plebiscite was necesary bofore the temporary character of the control could become permanent. 1 The United States probably based 1ts polley on the statoments

IJ. N. S. C., Off. Hec., 3rd Yr., 240th Heeting,

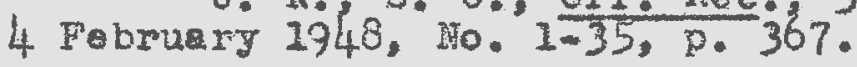


lssued by offlelals of the Indian government. Hehru, speaking before the Constituent Assembly in New Delhi on Novenber 25, 1947, declared:

We did not want a mere accession from the top but an association in accordance with the w11 of her people. We go go to Kasheir to protect the people and as soon as this duty is discharged our forces need not remain there and wo shall withdraw them. 1

The Prime Minister of India clarifled his views in other statements saying that until Kashmir wa completely froo of invaders, no possible plans could bo made for holding a plebiscite.2

The United States Proposes

Second Commission for Indian-Pakistan Dispute

On April 21 the United States sponsored jolntly with the United Kingdom, Belglum, Canada, ChIna, and Colombia a resolution that would establish second Unfted Nations comission for India and Pakistan. The terms of the resolution were, briefly, that a five-man commission would be set up to go directly to the sub-continent and offer its good offices and mediation efforts to the two parties. Paiclstan was asked to withdraw all 1 ts nationals not nomally residents of the state and when this wes accomplished India

India, Information Service, Kashmir, A Factual Survey (New Delh1; December, 1956), pp. 73-76.

2India, Information Service, Kashmir, 1947-1956, Excerpt from Prime Minister Nehru's Speeches (New Dolh1: United Press, 01d Secretarlat, 1956, p. 11 . 
would remove all lis troops. The Indian governont was to be responsible for recruting local people to mat in peace and ordez. 1

Austin, speking to the Councli just before the final adoption of the rosolution, insisted that all political parties should be fairly represented within the government or the state, and this principle was later included in the resolution. He also added that his government was pleased to see that both Pakistan and Indla had agread to settle thelr dispute through peaceful moans. The American delogate placed special emphasis on the right of the people to declde their future by pleblscite. Austin closed his romarks by noting that responsible Indian leaders had procleimed the desire and vilingness to see the dispute solved by plobiocite under international auspioes.2

The United States served as member of the second United Nations Commision for India and Pak1stan (JWCIP). Austin accopted the appointment of h1s country on May 7, 1948, and representing the United states was J. Klahr Fudile. The American delegation consisted of military and political adviser as well as a socretarial staff. 3

The Kashir situation, according to washington, now Apre1, 1948.
p. 20. I01d., 3rd $\mathrm{Yr}$. . 284th reeting, 21 April 1948, ${ }^{3}$ Ibid., 3rd Yr., 289th leoting, 7 May 1948, p. 5. 


$$
-14-
$$

had priority on the gonda of the Security Coune1l, Austin observed that both parties retained armed forces in Kashmir, regardiess of their pescerul intentions of solution. He later aded that possibly India and Pakistan did not want to settle thelr differences over Kashmir. 1

The resolution of April 21 was in substance not agreeable to either India or Pakistan. In letter to the President of the Security Counc1l, Zafrulla Khan of Pakistan expressed the following view: "Measures indicated in the resolution are not adequate to insure free and imartial pleblscite, and the government of Pakistan cannot carry out obligations sought to be lald upon them by the resolution." 2 Mr. P. P. Plilal, the representative of India wrote the Security Councll that his government could not lmplement those perta of the resolution concerning the pleblscite administrator. ${ }^{3}$

American Delegate Comments on Powers of UNCIP and Interpretation of Pacific settlement

The American representetive, Warren Austin, supported the 1dea of widening the powers of the commisalon. He advocated that it report to the Council on the Pakistan charges against India in the Junagadh and genoclde cases. New Delhi

IU. N., s. C., off. Rec., 3rd Yr., 304th Meeting, 26 Hay $1948, \mathrm{pp}, 20-21$.

${ }^{2}$ Ib1d., 3rd Ir., Supplement for hay 1948, p. 91. 3 Ib1d., p. 92. 
did not want the UNCIP to investigate these charges. 1 Nevertheless, Austin suggested that the comission investigate and submit its results to the Council, and then the Council would instruct the mediatory body as to its later objectives. 2 This was considered a pro-Pakistant move on the part of the United States alnce it colncided with the proposals of the Pakistani delegation. India strongly asserted that this was not an international problem and the Junagadh and genocide claims of Pakistan were strictly a domestic matter to India alone. The United States wanted all these matters referred to the UNCIP, but with the understanding that the Kashmir issue had first priority and the other matters would be taken up at the discretion of the Council.

At the 304th meeting of the Security Counc1l, Austin requested the Counc1l to interpret the Charter of the United Nations. Specifically, he wished to know what the obligations were upon parties in a dispute under the "paclfic settlement" provisions of the Charter. Perhaps, he continued, they might be determined and applied to this dispute or at least

Ipakistan charged India with aggression resulting from India's invasion of the State of Jungadh. The ruler, a woslem had acceded hls state to Pakistan. Indian troops entered the state, deposed the ruler, and held a plebiscite. The Hindu jorlty voted for India. Karachi also charged India with genoclde of the Woslem majority in Kapurthala as a result of the communal upheaval. Pakistan claimed 235,000 Huslims were masaced.

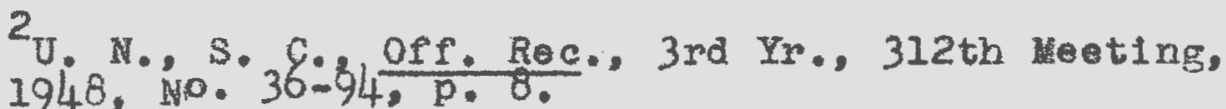
3 June 1948, No. $36-94$, p. 8 . 
ostablished as arocedent for future parties to disputes. ${ }^{1}$ His query went unanswered.

The comision did not arive on the sub-continent unt11 the second week of JuIy, 1948, some six months after the parties had given thorough account of the situation to the Security Council, and some three months after the Council had passed a resolution creating feeble attempt at solution. When the commission arrived; the fighting had bean renewed with interse vigor; thousands of civilians as well as soldiers were being killed in the confllct. Nevertheless, in the security Council on August 30, 1948, Austin declared that no emergency existed in Kashmir. The United States at this time strenuousiy objocted to having tho Kashmir issue ineluded on the provisional agenda of that body; 1to position was that the commision's objectives were olearly set forth in paragraph 17 of the resolution of April 21, and the commission had not asked for assistance. 2 Whington felt that the comission could well handlo all negotiations and mediation that needed to be accomplished in order to effect cease-flre and solution in the dispute. 3

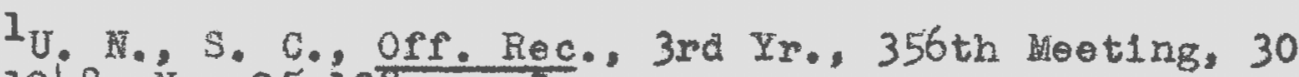
August 1948 , No. $95-108, \mathrm{p} .3$.

${ }^{2}$ Paragraph 17, Resolution of April 21, 1948, reads: "The Commission should etablish in Jamm and Kashmir such observers as it ray require of any of the proceedings in pursuance of the measures indicated in the foregoing paragraphs."

3U. N., S. C., off. Rec., 3 rd Yr., 356th Heeting, 30 August 1948 , 10. $95-108$, p. 4. 
Secretary of State George C. Narshall, speaking before the Goneral Assembly less than month later, partially revised his country' attitude. He found the situation charged with great dangers that threatened world peace, but he st1II volced the oplnion that, slnce both parties maintained their flingness to use pacific means in settlement, an immediate conclusion could bo clearly envisioned. 1

The Cesse-Fire

By January 1949 the commission was able to bring about a cease-fire agreement between the parties. Further agreements were made on truce lasues, demilitarization of the state, and a plebiscite. The greatest stumbling block was how and hen to implement these agrements. Thereupon, the American delegate, Philip Jessup, prolsed both governments for thelr statesmanlike action on this issue. He and his government, Jessup continued, looked formard to an early settlement. ${ }^{2}$ The Akterican delegate gave much of the crodit for the case-flre to Pakistan and Ind1a, since It was to their advantage, for nolther country could afford to bear the cost of war at this crucial timo. Ifttlo did

IUnited Nations, General Assembly, Official Records, 3 rd Session, Part one, 139 th Plenary heeting, 23 September 1948, p. 41. Hereafter roforred to as U. No, a. A., off. hee.

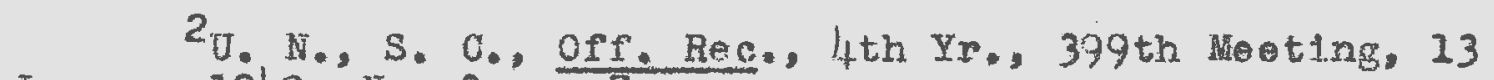
January 1949, No. 3, p. 7. 
Jossup know that the basic 1ssues on demilltarization and plebiscite proposala would never be resolved; at least they have not been in the docade whtoh has pased.

\section{American Policy in the Firet Yoar of the Kashmin Deadlock}

In summaring American polioy in the first cruciel year, the writer belleves that Washington was partial to the Pakatan argument on the 1saue. It was not a midie of the road course, nor was it a "do nothing" poltcy. It did without question support the ldea that a final settlement of the dispute would rest upon a vote of the Kashmirls themselves. Both parties agreed to thas prinelplo and it was not Imposed upon thom by any Securlty Councli resolution. American policy further mphasized that the pleblscite should be held under Unfted hations auspices, preferably under plebiscite administrator. 霜ashington fixst encouraged the ldea that India and Pakistan hold informal conversetions on theis problems. From informal talks American delegates recomended that a threeman comission be created to act as mediators. This first cormlssion was a complote fallure. Whe United States then sponsored resolution establishlng a second comission, wh th enlarged merbership and stranger powers. Thia second comisaton was able to acompli four major agreementa: cease-firo, truce, demilitariation, and a plebiscite. The cease-fire was implemented in January 1949 but the romalning three heve been in question for tho past 
$-19-$

ten years of the deadlock. 
HES HATHODS OF SOEUTION

India Suggests Arbitration on Agreed Issues Throughout 1949 the UNCIP was unable to bring about any substantial progress on the Kashmir 1ssue. There was one note of hope during the year; however; it came with the appointment of Admiral Chester W. Himitz as Unitod Nations Plebiscite Administrator for Kahmir. The Stato Department made it clear that he represented the United Nations an international organization and not the United States. 1

A signiflcant change in the method of solution occurred in the Indian position. Speaking before the General Assembly. Sir Benegal hau declared that as far a Kashmir was concernod, India was not wholly opposed to the 1dea of arbitration on agreed issues, but these 1ssues would have to be clearly defined beforehand. He repeated that India continued to desire a peaceful and atablo solution to the is sue. 2

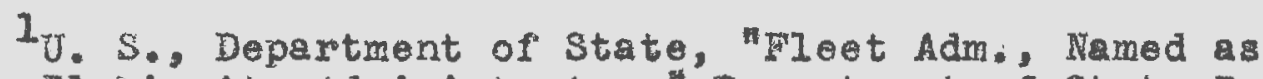
Rasimir Plobiscite Adminiatrator," Dopartment of State Bulletin, $\mathrm{XX}$ (March, 1949), 419. Hereafter referred to as V. S., Department of State Bulletin.

$$
\text { 2.. H., G. A., off. Rec., 4th Session, 222nd Plenary }
$$
Heoting, 21 Septomber 1949, p. 10 . 
In October 1949 the Pakistan government accepted arbltration of truce issues as means of pusbing the dispute toward an erly settlement. The Indian government refused arbitration, saging that the issues to be arbitrated were too ambiguous and not sufficiently defined. I

\section{UNCIP Reports to the Security Council}

The idea of arbitration had been first suggested by the commision on all differences of lmplementing the truce greoment. Later in the jear, Hernando Samper, Chalrman of the UNCIP, informed the Councll that the commission could do no more to bring about a settlement since it had been unable to get olther party to implement the resolutions of August 13, 1948 and Jenuary 5, 1949.2

In the August 13 resolution India and Pakistan agreed to the complete w1 tharawal of all Paklstanl troops from Kashmir as well ag all non-Kashmirl nationals not normally residents of the state. When Pakistan had completed this movement the combsion would notify the Govemment of India.. New Delh1 would then whdraw its forces from the state on stages to be agreed upon with the comission. India and Pakistan also consented to the principle of a plebiacite for the poople of Kashmir in determining their future. The two governments gave thelr full consent to

$1_{0}$., Department of State Eulletin, "U. N. Action Heviewed," XXI Toctober, 1949), 654.

2U. N., S. C., Off. Rec., 4th Yr., 457th Mooting, 17 December 1949, No. 53, p.2. 
the URCIP resolution of January 5, 1949, which reiterated the plebiscite proposal as soon as the truce agreement and piebiscite amangments had been complotod. Inaia and Pajstan gave full approval to the appolntment of UN pleblsclte administrator. ${ }^{1}$

The United Statos fowd that the commsion poport In Decomber 1949 suggested an equiteble sulution to the Kashopir 1saue. Washington was consistent with its previous stand on Kashalr in taking the view that the future of the state would bo determined by the froely oxprossed w11 of 1ts people. The State Department noted that the plans for solution were floxiblo enough to lend themelves to modification by the two parties concerned. The Amerlcan deputy reprosentative to the Counc11, Errest Gross, seid these were not the only solutions; others undoubtedly oxistod and could be armed at by India and Paxistar.

Washington Suggests Appointwent of a V. N. Representetive to Replave URCIP

By 1950 the United States seemed to show more interest in the 1ssue, for it sponsored resolution jolntiy with Cuba, worray, and the Jnited KIngdom. Washington belleved

\section{${ }^{1}$ Josef Korbel, Danger in Kaghmir (Princeton, New} Jersey: Princetion Univerity Fress, 1954), pD. 312-19.

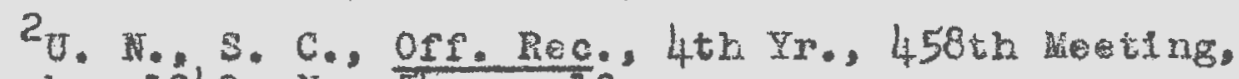
29 Decenaber 1949, No. $54, \mathrm{p} .13$. 
that the problem had to be solvod along broad polltical grounds. The plan called for both parties to gree on a workable outilne of demilitarization and then to carry it out a a prerequiste to the final stage of a plebisclte. This plan for reducling the forces called for minimum number to a point where they did not interfere with the free expression of public opinion in the proposed plebisolte.

Wasington wantod this demilitarization problom accomplished on both sides of the cease-flre 11ne; Indien troops must not go into the northern or Paklatan-held area of Kashmir. It heartily approved the UN plan to appoint a representative to supervise the 1 mplementation and assist in the preparation of a prozram of demilitarialing the state. 2 This American sponsored plan for Kashir was rinally adopted on march 14, 1950, embodying the above ldeas and terminating the second UWCIP. ${ }^{3}$ India, in a note to the Councll, proposed a three-man UN team, one appointed by Ind1a, one by Paikstan, and one by the President of the Security Counci1.4 Pakistan approved the resolution, but with reluetance. In April 1950 the Council consented to

${ }^{2}$ U. I., S. C., Off. Rec., 5th Ir., 467th Heoting, 24 Fobruary 1950, No, $9,0.15$.

Ib1d., p. 17.

3U. N., G. A., Off. Rec., 5th Session, Supplement No. 2, p. 13 .

4U. N., S. C., off. Rec., 5th Yr., 469th Neoting, 8 March 1950, No. 11, p. 5. 
the appointment of Sir Gen Dixon as UN representative for India and Pakistan.

Washington Notes Irprovement in Indian-Pakistan Relations

The State Department at this time was quite pleased to learn that the Prime Ministers of Pakistan and India had met in Now Dolhi to pach acord on minority groups in their countries. When the two nations signed a treaty guaranteelng the protection of minorities, the United States saw the opening of a now ra in better relations botween India ana Pakistan. ${ }^{1}$

Noting that this Prime Hinisters'meting in India might lead to further oocord in Indian-Pakistan relations, the United States did not want the Security Counc1l to consider the question of blame or guilt in the Kashmir dispute. What it did want was to increase the strength of the UN mediating representative as far as it was proper to do so. "In ajing this we cast no aspersions watsoever upon the parties," Austin expleined." Their problew was excoodingly difficult, he continued, and tho council was not trying to enforce something by punfshment, coercion, or anything of that kind. Austin also declared that the Counc1l

$I_{U}$. S., Department of State Bulletin, "Department Encouraged by Indit-Pakistan Talks," XXII (Apr11, 1950), 631.

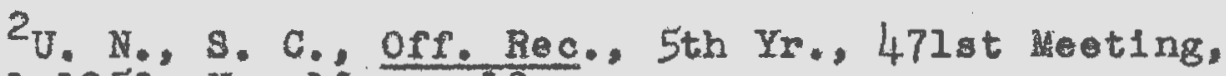
12 April 1950, Ho. 13, P. 10. 
was attempting to use the finest of Instmuentallties in all alsputes, pacific gettlement.

\section{Sir Owen Olxon's First Report to the Security Council}

Unfortunately, D1xon's mediatory offorts were unavailing. In transmitting his report to the council in September 1950, he informed the body that all bis suggestions had fallen on deaf ara. Both partles failed to agree on any of the preliminary measures of demilitaxization that fiust precede the plebiscite. India wantod Pakistan condemned a an agressor, a crare that wastngton did not wish the UN representative to even conaider. Dixon informed tho Indian officials that he ras instructed by the Couneil not to pass any statements on this subject. India later claimed that Dixor aid make a feoble ottempt at condeming Pakistan a an Gegressor in Kashmir. Hixon's statemont ran to this effect:

Wh thout going into the causes or reasons why it happened, which presumably fomed part of the history of the sub-contirent, I was orepared to adopt the viow that when the frontler of the State of Jammu and Kashnir was crosad, on I bellave 20 october 19!7, by hostile elexents. 1t was contrary to international law, and that when, in way 1948, as I believe, units of the regular Pak1stan force moved into the territory of the state, that too wa inconsistent ith interational law. 1

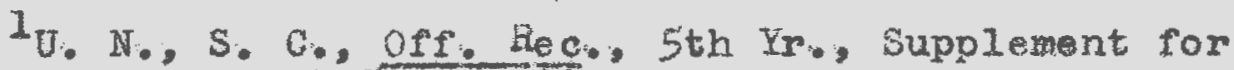
September-Dacembor 1950, . 29. 
Amorican Delogeto Expreases Apprehension over Constituent Assembly in Kashmis

In February 1951 the Kashmir dispute was oncs again placed on the agenda of the securlty Council. The State Department observed that both countries were st1ll of the oplaion thet the issue could be settled peacefully. Ernest Aross, the American delegate, wanted the Counoll to "help narrow the field of disagreement." He also expressed concern over the work of the authorities in the Indian controlled rea of Kashmin, and their plan to determine the future affilation of the atate whout a pleblacite. The Indian government had given its permission for the convening of constituent assembly in its area of the state. wahington held that in such an event Irdia would violate 1te earlier agreements in the UNCIP resolutions. In speaking to the Councll, Gross noted that:

The Unt ted States government firmly believes that there can bo no real and lasting settlemont of the Kashmir dispute which is not acceptable to both parties. Any attenpt to decide the issue ithout the consent of both parties would only leave constant and explosive irritant in the relations between these two governmentr, an irritant which would effectively prevent the bringling about of peace and security in South Asla. I

Weshington took a flim stand that the Council ahould not ccept or epprove plebiseite conducted without the

.T. M., S. C., off. Rec., 6th Yr., 532nd Heoting, 21 February 1951, p. 12 . 
latter's approval or Ithout a supervisor appointed by the Council. The very existence of a constituent assembly in Indian-hold Kashmir, able to determine Kashmir's future, would obviousiy not be in accordance with the terms of a fair and Impartial plebiscite. ${ }^{1}$

The socond UN Fepresentative

In late February 1951 the United 3 tates proposed a joint draft resolution with the United Kingdom, asking the Security Council to re-appoint a UN representative to help the parties effect a demilitarization of the state. The mediator would present possible detalls and plans for carrying out the plebiscite agreable to both parties. Ho would be glven greater powers, with atrengthened and amplified term of reference. The demlitarization proposals ould be drafted by the mediator and then presented to India and Pakistan. If at all possible, ho would attempt to make use of these two a1ds: a United Nations force during the demilitarization and plebisolte poriod, and an attempt to get both parties to accept arbitration upon points of difference left over after negotiations have been made and carried out by the UN representative.

Washington belleved it was the duty of the security Council to call to the attention of both Indie and Pakistan the1r obligations under the United Nations Charter to seek

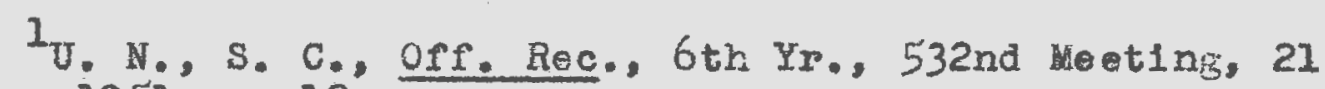
February 1951, p. 12 . 
a solution by all manner of peaceful means, including arbitration. 1 Although India had suggested this method of solution as early as september 1949, it was now opposed to arbitration. Paxistan also rejected this Washington proposal since it Implied a reference to partition of Kashmir. harachl would nover consent to a plan involving partition. 2

How Delhi Objects to the Fesolution

India tried to reassure the United States and the other Councll members that the constituent assembly in Kashmir was not intended to prejudice the problem as it existed before the council. The Indian representative malntalned that his nation was secular state with minority rights guaranteed to all regardiless of race or religion. He relterated the principle that Kashmir was legally and integrally a part of the Indian Union. By federal law, the state was permitted to draft or formulate Its own constitution, and to convene a constituent assembly for the state. India, he declared, could never permit the entry of foreign troops into the state, or in any other part of India. As for the Anglo-American draft rosolution, the Indian government was wholly unable to accept 1 t. 3

IU. N., S. C., Off. Rec., 6th Ir., 532nd heeting, 21 February ig51, p. 15.

${ }^{2}$ Ibid., 6th Yr., 534th teeting, 6 Warch 1951, p. 2. 3.101d., 6th Yr., 533rd weoting, 1 March 1951, p. 9. 
Nehru, at a press conference some woeks later, announced that India would never accept artitration on the differences confronting India and Faistan. He declared that India coula not upsetnor violate 1 ts constitution bocause of some resolutions put forward in the security council. 1 Due to the strenuous objections by India and Pakistan, the Unfted States found it nocessery to tono down 1 ts proposals to what Ernest Gross called "the irreducible machinery." since the two parties wanted the UN representative to utilize the previous UNCIP resolutions, the American delegation added the following amendments to its latest proposals:

(I) The Us Representaitve would effect demilitarization on the basis of the UICIP resolutions of 13 August 1948 and 5 January 1949.

(2) If no agreement is made on demilitarization plan after three rionth period, then the UN mediator is to report back to the Counc1l.

(3) The two parties should accept arbitration on those points reported to the security Councll by the UN Reprosentative. The arbitrator would be appointed by the President of the International Court of Justice.2

The State Department regarded the arbitration proposal as the key to the resolution. It attempted to pro-

India, Information $3 e r v 100$, Kashmir, 1947-1956, Excerpts from Prime Minister Nohmis Speeches (Now DeIh1: United Press, old Secretariat, 1956), p. 26.

${ }^{2}$ U. N., s. C., off. Roe., 6th Yr., 537th lleoting, 21 造arch 1951, p. 9. 
vide both partios with recommendations neoded in sottling the dispute. Although India and Pakistan rejocted it vigorously, ashington would not agree to 1 ts removal from the resolution.

The two disputants were given the opportunity to present their views on the revised British-Amerlcan draft resolution. The first to speak to the Council was sir Benegel Rau of India who again opposed the idea of arbitration on for differences. India, he declared, could never submit a purely domestic matter to an international arbitral body. I several deys 1ater the Pakistanl representative informed the councli that the revised resolution was acceptable to his government, including the item on arbitration. 2 Disregaraing the Indian objections, the Council adopted the resolution by elght votes in favor with three abstentions.

Selected to serve as the now Unlted Nations repreaentative for India and Paklstan was Dr. Frank P. Greham, who was appointed on Apr11 30, 1951. Thls time the mediation efforts were to be turned over to a noted Amerioan educator and former president of the University of North Carolina. His efforts on the sub-continent were frustrating for all three parties since no agreement could

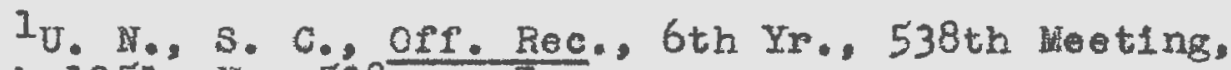
29 March 1951, No. $538, \mathrm{p} .7$. 540, p. ${ }^{2}$ Ib1d., 6 th Yr., 540th meeting, 2 April 1951, No. 
we reached on laplementing the cempitarigation of the state. After fifteen weeks of nezotiation and mediation ending in fallure, Grahar submetted his report to the Socurity Couno1l.

\section{Constituent Assembly Again Annoys} the state Department

In late Mag 1951 the United States delegation to the Unlted Nations as quite disturbed over the convening of the constituent assembly in Indlan-held Kashmir. Gross sald hls government believed that no lasting settlement to the dispute could be complished if the two parties did not ablde by the methods of solution greeablo to both. If the action proclalmed by Prime Minister Abdullah of Indian-held Kashmir were carried out, and India sanctioned this action, Gross malntained, no possible solution could be envisioned. Weshington announced that it would regard any acts of the constituent asombly to sottle the accession matter as comoletely null and vold, regardess of what asurances the Indian governent had already given to the Counc11. 1

The Second Graham hiolon

The Security Council was forced once again to place the Kashmir dispute on Its agenda for discussion. The

10. H., s. C., off. Fiec., 6th Yr., 548 th Meoting, 29 May 1951, No. 548, p. 15. 
Ameriean delezation saw the urgency of the issue and in-

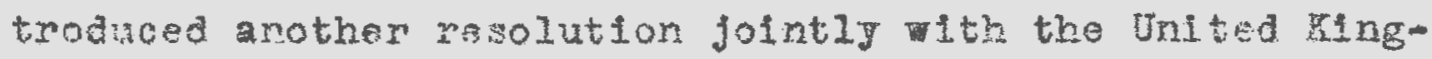
dom. It resfermed the objectios of India and Palsistan to actio the dispute pecefully ith a desire to determine the will of all the people of the Jammu and Kashule state through a free and lmpartial plebiscite conducted under the supervision of a UN team. Dr. Craham was aked to continue his efiorts and to seok a plan of demilitarization for the parties. Fingliy, the Councll requested Graham to report his fluding no later then alx weeks after the resolution went into effact. The Stete Department belleved that the demilitarization proposals would have to form the golid basis for any future agreoments I

Groham's acond report was given to the securlty Counc1l at the Palais De Cheil1ot, Paris, on Decomber 18, 1951. Negotiations had been carried on wth Zefrulle Khan of Pakistan and Bonegral Rau of Indis, but whout sucess. One month later, on Jamuary 12, 1952, the American delegste noted that Graham did not attempt to impose any settlement upon the two parties. The mediator, ho continued, merely suggested that India and Pakistan agre to certain issues before sottienent could be complished. These Qgread lsaces wore:

(1) The scope of demilitarization and the number of troops to remain at the end of

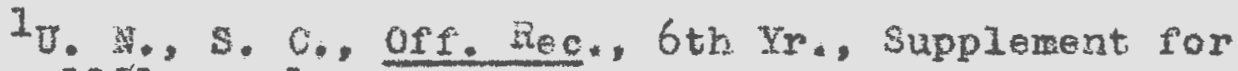
November 1951, p. 1 . 
the period of demillterization.

(2) A dofinite perlod of demilitarization

(3) An otablishod doy for the introduction into office of the Pleblsclto Administrator. 1

The State Department believed that these three 1ssues formed solld basis upon which India and Paistan could arrive at an agreement. The American deputy representative axpressed confldence that these issues could be solved and negotiations should not be halted; in fact, Graham should return to the sub-continent, basing further mediatory efforts on the resolutions of the Couno11.?

Further Hation Efrorts

Upon the adoption of an American resolution, Graham was instructad for the third time to ald the parties in settlement and report back to the council at the end of Maroh 1352. This ras to be "final atterapt" to get the disputants to agreo on plan for domilltarization. Whon Graham gave his third report to the security Councli bo again reported fallure. There was one signifleant point In his findings and this was that he considered it an opportune time to consult the Plebisclte Administrator, Chester Nimltz on proliminary plans for lmplementing plebiscite. Unfortunetely, India and Pakfstan objected to this suggestion

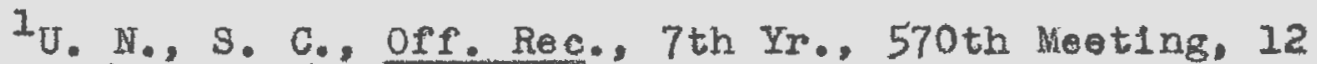
January 1952, No. $570, \mathrm{p} .10$. 571. p. 21.

Ib1d., 7th Yr., 571st Weeting, 30 Jamuary 195e, No. 
for calling in the administrator as premature. I

The Council was not discouraged over Graham's fallure on the sub-continent. For the fourth time Graham was sent by the Council to negotiate with the parties, flrgt in New Tork and then in Geneve, Switzerland. Returning to New York with hls fourth report, he submitted his flindings to the Security Councti on September 11, 1952. Summarlzing the problems confronting the disputants, he then made recommendations, and noted the difficulties of his position as mediator. The fourth Greham mission had ended in fallure. ${ }^{2}$

Discussion in the General Assembly

Speaking before the General Assembly at its 380 th meeting, Socretary of State Acheson mentioned very briefly the jor issues confronting the United Nitions. Although not specifically naming the India-Pakistan dispute, he did sey the General Assembly could "create an atmosphere favorable to settlements" in accord with the principles of the Charter. He also declared that these settlements should be worked out by the parties themselves. ${ }^{3}$ Perhaps Achoson was able to see thet the council could not perform its appointed tagk of establishing conditions sultable for the growth of a

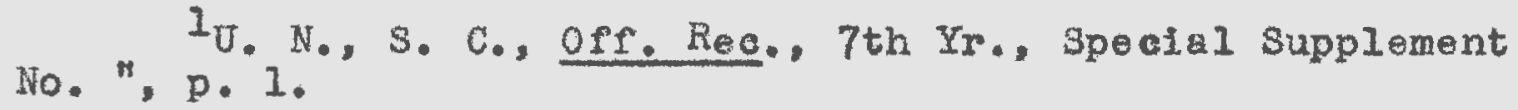
605 , p. ${ }^{2}$ Ibid., 7 th $\mathrm{Yr}_{\text {., }}$ 605th 践eting, 10 0etober 1952, No. 30. N., G. A., Orf. Hec., 7th Session, 380th Plenary Heeting, 16 october 1952, p. 42 ? 
peaceful conclusion of disputes. Fe saw in the Assembly a powerful force of world oplnion that would compel the parties involved in a dispute to settlo it amicably, and as rapidy as possible. The Kashmir doadlock had been before the Councll for a period of four yoars and 1 t was well into its fifth year with no solution found by the appointed ars of the United Nations.

India was apparentIy willing to let the ratter rest for the time being, for her cielegates to the General Asembly falled to make any reference to the issue in November 1952. The iasue, howover, was not rorgotton by the Paklatant delegate, for on November 12 Zafrulla Khan anrounced that the Council's Inability to solve the dispute had not enbanced or strengthened the authority and prestige of the United Nations. He placed the responslbility for solving the deadlock upon the security council and spectfically upon the five great powers; yet he saw his own government's actions as beyond reproach. This have been the earliest evidence of Pakistan's "frustretion" in the dispute. I

\section{A Fifth Anglo-American Heaolution Sends Graham to the Sub-continent}

As result of the pressuring and "needing" of the Pakistarl dolegation, the Security Councli in late 1952 roted atill another resulution prepared by the Inted States

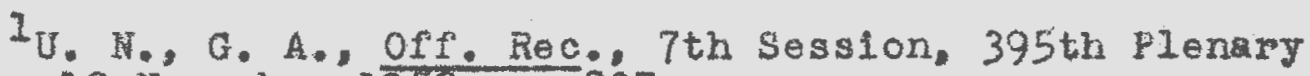
Heoting, 12 November 1952, p. 237. 
and the United Kingdom. Speaking for the former, Frnest Grose Indiceted that settlement mist be based upon these prineiples: 1

(1) Agreebent by both parties to the fol1tical questions involved.

(2) An \&grevent reachod by hoth partios themselves.

(3) Regotiations based on compromise:

(4) The future of the state to be deteralned by the free and impartial plobiscite under United Hations uspices.

This rosolution endorsat the recomendations made by Graham in his rourth report. The problem had been narrowed down to one basic issue, and the Anerican-sponsored plan would help overcore this 1 sque. Indis and pakistan ohould negotiate win the lin of reaching ageement on the specific number of forces witin certain eros or ranges suggested by Graham. Thls was the one proolem upon which the two disputenta had falled to agree. The draft resolution ondorsed Graham's provious suggestion that "thls number should be between 3,000 and 6,000 armed forces remining on the Parlatan aide of the cosso-fire line, and botuen 12,000 and 16,000 armed forces remining on the Indian side of the Ilne." steter the demilitarization period hac onded, all Fakigtand nationals, troops, and tritesnen woldd be withdrown from the Pajistan slee of the line. On the Indian side all the $1 x$ troops ould be whoraw. A small token force woula remain in each area to malntair law ona orcer, but the

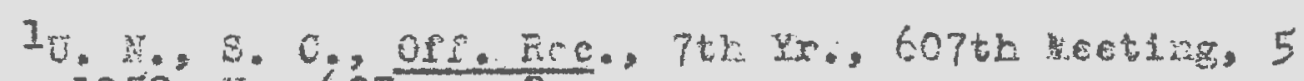
December ig52, No. 60́7, p. 2. 
force or locel pelioe would give due regard to the freedom of the future plobisalte. 1 Grahmen was aked to attempt a fleth try at mediation and the governments of India and Pak1 atan were asked to colluborate and asist him a much as posstble. Washington viewed the stuntion as belng very semous, earing that if no further action were to be taken, and the condition continued to drift, there would be great danger to a11. 2

The Pak1stant delegate, S1r Nohamed Zafralla Than, was w112lag to accept the Ameriean proposal, provided that India agreed to keop only troops on 1 ts alde of the ceaseflre line and no areur or artillery. The Pakistanl army would move out of 1 ts ocoupled area on this basis. 3

Tho Indian position had lways been that all Pakistant armles, aur111ary untt, and other forces should withdraw from every inch of Jammu-Kashmir territory, and the Azad force In Festern Kashmir (under Pakistanl control) should be diserwed. India alone would determine what forces it would withdraw. Jawaharlal Nohru had said in July 1952

It was always a condition that we must have enough forces in Kashmir, and we were

2., N., 8. C, orf. Rec., 7th Ir., 607th wieting, 5 December 1952, 110. $607, \mathrm{PP} .5-9$.

2v. S., Department of State Bulletin, "U. S, Vlews on Prospects for setting Kashmir Controvers," XXVII (December, 1952), 1030.

3.. S. Department of State Bulletin, "The U. 8. in the U. H." XXVII (Deember, 1952). 1042. 
the fudges of thet. 1

On Docember 8, 路s. Vijaya Lakshul Pandit popted to the security Councli that her government would permit a small Azd force on the Pariatani side of the cease-fire Iine, but that ate administrative authoritios mat bo local people and not Paklstanl nationals. Miltary forces on the Indian side, she continued, had to be flxed in number by Indian military athorities and not on the recommonations of the UN military adviser. Madam Pandit relterated that any alternet1ve figures must be justified on realistle considerations of securlty, and not be put forward merely as a matter of politioal bargaining or appeasement. In her closing statements she sald that India found it necescary to reject the American proposals in the draft resolution. 2

Novertheless, the Anglo-American resolution was adopted by the Coune1l and Graham was sent for the fifth time to the sub-continent. Upon his return to Now York in Warch 1953 he transitted his roport, informing the council that he had been unable to settlo the jor aifferences needed before settlement could be accomplished.

India, Information service, Keshmir, 1947-1956, Excerpts from Prime Hinistor Hehru'g Speeches (New DeIhi: Unt ted Presis, Old Secretariat, 1956), . 31.

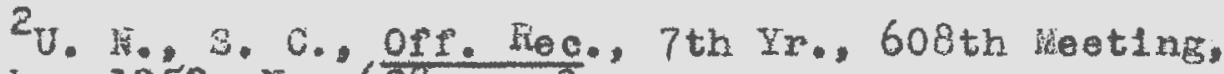
8 Decomber 1952, 10. 608, P. 9. 
Amerlean Polley during the Period 1950-1952

Washlngton, oncouraged by Indian and Pakistani advances, sponsored jointly wh other Counc1l members a resolution terminating the UNCIP and establishing singlo United Nations representative. The State Department wanted the representat1ve, Sir Owen Dixon, to prepare a program of demilitarization of the state. H1s orforts onded in fallure. Five accessive resolutions sponsored by the Unlted States and the United Kingdom sent Dr. Frank : Graham to the sub-continent s the second United Nations representative. All five at empts were unsuccessful.

phe State Department expressed great apprehonsion over the convening of the constituent assembly in Indianhold Kashmir. It denled the claimg of this body to determine Kashmin'suture whout holding atate-wide pleblaclto under United hations ausices. American delegates declared that if the assembly concluded thelr plans yo approve the Meharaja's accession, then no possible settlement could be envisioned in the dispute. Wew Dolni replied to these American foars by indicating that the assembly in no way prejudiced the iasue; meanwile, it encouraged the asembly to convene in srinlgar, capitol of the atate. triting on Agericai pollcy and its development during this perlod, Jarry N. Howard, UN adviser, noted thet the United States had sought a constructive and equitabl. solution to the Kashir problem through the United Nat1ons, 1ts organs, and by direct negotiation with each pary. The 


$$
-40-
$$

hemet of American polley as soon by Howard involved thi principle:

If and when settlement came, the United States would wart it as a result of free agreement by India and Pakistan with the afd of the Councli and the un representative. 1 


\section{CEAPTER IV}

\section{MILITARY AID TO PAKISTAN \\ The "Northern Tier" Defense System}

The moj spokesman for the Indlan government, Prime inister Jawaharlal Nehru, proclaimed in August 1952 that the hashmirls would declde tholr future, and if they did not wish to stay with Inda, then India would not keep thom against their 111 . H1s attituda would change when it became known that Pakiatan had planned to accopt military ald from the Inited states. ${ }^{1}$

Choster Bowles, American Ambasador to India, in the same year saw a drastic cheng in U. S. policy occur after the national electlons in the unfted States. This change, he notlced, was opecially evident after the 111-t1med bid had been extended to Paklstan to joln the Midle East Defonge Organization. This was greatly infundergtood in India. 2

The State Department and its m111tary atrategists

${ }^{1}$ India, Information Service, Rashmir, 1947-1956, Excerpts from Prime Hinister Nehru's Speeches (Now DeIh1: United Press, 01d Secretariat, 1956), p. 32 .

${ }^{2}$ Chester Bowles, Ambassador's Repart (New York: Harper and Brothers, 1754 , p. 349. 


$$
-42-
$$

envisioned the development of a "northern tier" defense ayatem, which would include military ald to Pakistan.

It would be basod on a close political alignment with Turkey and Pakistan. This was whout doubt the most outstanding development in the rea in in $^{2}$ 1954. The long term cost for the milltary program would run from 250 to 500 mililon dollars. This program was al med at repelling the possibility of any Soviet aggression in that area of the world. The United States whed to establish a chain of local defensive arrangements operted by the nationals of those countries who wanted this a1d. It did not desire bomber beses, as some governments thought.

\section{Stipulations under Miltary Ald Program}

Thus, in 1954 the Rashmir ituation changed abruptly when the United States offered military ald under the Mutual Defense Assistance Act to those nations needing and asking for such aid. Legialation under this grant for milltary ald ataded that:

Nations recelving aid agree that equipment, materials, or services provided 111 be used solely to mintain its internal security, for legitimate self-defense, or to permit it to particlpate in the defense of the area, or in Unfted tions collective security arrangements and measurs. It furthor agrees not to act in aggression againgt any other nation. 1

$I_{U}$ S., Department of State Bulletin, "The Problem of Security," XXX TMarch, 1955), 447. 


$$
-43-
$$

The overelgn state of Paklstan requested such ald from the United states under this act. On February 25, 1954. President Elsenhower complied with the Pakistani request, but he assured the world that if this ald was misused or directed against another in aggression, he would Immediately undertake appropriate action within and without the United Nations to thwart aggression. The President Informed the Indian government that such military ald in no way changed our relations with Ind1a, and if it desired military ald, the United States would give India the most sympathetic consideration. 1

Agreements signed betwoen Pakistan and the United States were completed in May, 1954, when both governments signed a mutual defense agreement at Karacht. The United States would provide military equipment and training assistance to Paklstani armed forces as well as a miltary advisory group.2 Article 5 of the Pakistan - American agreement provided that:

1. The government of Pakistan w11:

(a) Join in promoting international understanding and good $\mathbf{1} 11$, and malntaining world peace;

(b) take such action a may be mutually agreed upon to ellminate causes of international tension;

(c) make, consistent with its political and

$I_{U}, S_{.}$, Department of State Bulletin, "The Problem of
Security, XXX Tharch, 1955), W48.

${ }^{2}$ U. S., Department of State Bulletin, "The U.S. Pakistan Mutual Defense Assistance Agreement," XXX (June, $1954), 850$. 
economic stabllity, the full contribution permitted by its manpower, resources, racilities and general economic condition to the development and intenance of its own defensive strength and the defensive atrength of the free world;

(d) take all reasonable measures which may be needed to develop its defence capacities; and

(e) take appropriate steps to insure tho effective utilization of the economic and milltary assistance provided by the United 3tates. 2. (a) The Government of Pakiatan vill, consistent with the Oharter of the United Mations, furnish to the Government of the United states, or to weh other Governments a s the Partles hereto may in each case agreo upon, such equipment, terials, services or other assigtance as be agreed upon in order to increase their capacity for individual and collectlve self-defence and to facliltate their efrective participation in the United Nations system for collectlve security.

(b) In conformity th the principlo of mutual ald, the Government of Pakistan will facilitate the production and transfer to the Government of the United States, for such period of timo, in such quantitios and upon such terms and conditions as may be agreed upon, of raw and somi-processed materiale required by the United States as result of deficlencles or potential deficiencies in its orn resources, and which may bo vallable in Pakistan. Arrangements for such transfers shall give due regard to reasonable requil rements of Pakistan for domestic uso and commercial oxport.1

According to press releases from the State Department, the agreement signed by the Unfted States and Paklstan did not "involve any obligations on the part of Pakistan to provide milltary bases for the use of the United States." 2

$1_{\text {Mushtaq Ahmad, The United Nations and Paklaten }}$

(Karach1: The Times Press, 1955), pp. 147-48.

${ }^{2} \mathrm{U}$. S., Department of State Bulletin, "The U.S.Pakiatan Mutual Defense Asgistance Agreement, "XXX (June, $1954), 851$. 


\section{U. S. - Indian Relations}

When the decision to grant milltary ald was announced, many writers on Indian affairs in the United States volced violent objections. Some saw it as very detrimental to the Aslan relations of the Unlted States because it would release a pandora's bax of trouble, prevent or deley settlement of the Kashmir dispute, or cause extremist oloments in Pakistan to attack India, That was nooded, many advocated, was conomic ald, whlch alone could biting lmprovement in Indian - American relations. ${ }^{1}$

Some held that American military ald to Pakistan would drive needed development funds in India's budget into milltary expenditures in order to counterbalance Pakistan's ald from the United States. American policy In this area, they sald, should be confined to economic ald only. not military, and without any strings attached. ${ }^{2}$

India viewed the ald offer to her nelghbor with concern; In fact, she was naturally quite susplolous of these milltary pacts. Nehru declared that he could not understand why Pakistan had accepted American a1d; he informed the Indian parliament that the situation was most abnormal, and the ld was likely to create aggression

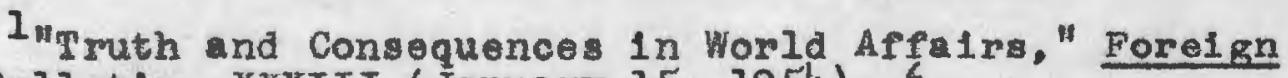
Polley Bullet1n, XXXIII (January 15, 1954), 6. " "Should U. S. Give Military Ald to Pakistan?," Forelgn Pollcy Bulletin, XXXIII (Fobruary 15, 1954), 4. 


$$
-46 .
$$

rather than prevent 1t. Mohru saw the Untted States as "Interferlag" In normal Indiampakisten relations and announced thet Indis would have to reconslater tho wholo Keshmix issue from an ontrolg differont polnt of view because aditional forces had boen thrust into Fakistan. Indla became ven more ausplelous of the United Ststes when mutror ran wild on the sub-continent thet the Aworlean Secretary of state favored the 1dea of partition of Kasmir long the prosont cose-flre 11ne. The ltuation became so procarlous that in the latter part of 1953 the American Ambassador to India, George V. Allon, problbited U. 8. Aitizens from traveling into Kashnir because of this ant1-American foel1ng. ${ }^{2}$

Ambasador 0. L. Hahta, Indian Ambasador to the Unitod States, brlafly summed up Indian forelgn poliey at this thes, doclaring that his govermment wated no entangling allimes. Indin, he noted, wanted time to grow and to develop 1 ts own country. Mohta saw this perlod as analogous to that of the Und ted Statea from 1798 to 1937.3

Mevertheleas, Indla would st111 fear Paklstan's

Irale, Information Service, Keshrir, 1947-1956, Excerots from Primo Minister Fehru's Speeches (Now DeIhi: Unted Press, 01d Secretariat, 1956), P. 38 .

2 Josaf Korbol, Donger In Kashmir (Frinoeton, New Jersey: Prineton University Press, 1954), P. 238.

3G. L. Mohta, "India in World Afrairs," Vital Speeches, XXI (JuIy 2, 1955), 1322. 


$$
-47 .
$$

territorial ambitions on the sub-continent. Speaking on Indian proparedness in evont of a Pakistanl attack, Nehru proolalmed that:

Nothing is more importent in the opluion of this goverment than to meke India economioally and m111tarily atrong - not In the $\mathrm{BIg}$ Power sense, beceuse $1 \mathrm{t}$ is beyond our capacity - but as trong as wo can 1 to defend ourselves if anybody attack us. 1

Economic Ald to India

Heng people who saw the strained Indo-American relations suring the porlod atrongly advockted an inorease In comomic aid to India, belloving that to allonato India with its groat influence in that area would mean alienation of other friende in Aste. ${ }^{2}$

Economic ald in the fom of grants and loans was given to India, though not as much as Indi sought. The sum of $1,028,000,000$ had been provided in the $J .3$. federal budget for conomlc and technical development for India, Pakiatan, and the Phllipplaes. By July 1955, India had signed alx operational agreements with the United States government 1nvoling louns of $\$ 72.5$ m11110n. Somo

$I_{\text {Shant1lal Kotharl, Ind1a's Fmerging Forelen Polleles }}$ (Bombay: Vora and Company, 1951), p. 69. Kothari has reproduced this statemant from Javaharlal wohra's, Independence and After, pp. 317-26.

2Ohester Bowles, "Partatership Which Must Not Fail," VItel Speeches, XVII (uarch 1, 1952), 304. 
twelve million of this was to go into teohnieal assistance, and ebout sixty mililon into dovelopment assistance. Although India would not accopt military ald, it would take other asistance in the form of loun and direct grants of needed meterials. ${ }^{1}$ The mere acceptance or this aid was to be used agalnt India by some writers and newspapers, for they saw this aid as being poured, not into India, but into Kashmir by the Indian government in an effort to influenco the Kashiris to remain with India. Hew Delhi has attempted some development of Kashmir bj bullding dams, water facllities, hydro-electric stations, and schools. 2

\section{Regional Pacts}

In 1954 Austral1a, France, Hew Zealand, Pakiatan, Thallend, the United KIngdow, the PhIllpplnes, and the United States 81 gned the South-East Asia Collective Defense Treaty known as sEaTo. It was not as strong as the North Atlantic Treaty Organization. 3

The SEATO paet provided for the settlement of disputes by peaceful means, the development of the ability to resist attack, and the promotion of economlc progress.

IIndia, Winistry of Extemel Afrairs, Forolgn Affairs Record, I (July, 1955), 153.

2 I0I York T1mes, April 25, 1957, p. 7.

3c. Engleton, Internatlonal Government (New York: Ronald Press Co., 1957). p. 569. 
The preamblo reads:

Reaffirming that in accordance with the Cherter of the United ations they uphold the principle of equal rights and selfdetermination of peoplea, and declaring that they will ournestiy atrive by every peaceful means to promote olf government and to secure Independence of a 11 countries whose peoples desire and are able to undertake 1 ta responsibilitios. I

Pak1stan would utilize the above to press its demands for an Independent Kashmir, or a Kagmir that could decide Itself to whom it would finaliy accede. Article 4 of the treaty noted that:

(1) Each party recognizes that ggression by means of armed attack in the Freaty Area agringt any of the parties or agalnat any stato or territory, whioh the parties by unanimous agroenent may hereafter designate, would ondanger its own peace and safety and agrees that it w11 in that ovent act to meet the common danger in accordance with its constitutional processeg. Measures taken under thi peragraph shall be immodiatoly reported to the security Couricil of the United Nations.

(2) If, In the opinion of any of the parties the inviolability of integrity of the territory or soverelgnty or political independence of any part in the Treaty Area or of any other state or territory, to which the provisions of paragraph one of this article from time to time apply; is threatened in any way other than by any fact or situation which might endanger the posce of the area, the parties shall consult Immediateig in order to agree on the measures which should be taken for eomon defence.

(3) It is understood that no sction on the territory of any state desicnated by unanimous

$I_{\text {Mushtaq Ahmad, Tho United Nations and Pakistan }}$

(Karach1: The Times Press, 1955), p. 150. 


$$
-50-
$$

agreement under paragraph one of this article or on any territory so designated hall be taken except at the invitation or with the consent of the government coneerned. 1

Sesretary of State John Foster Dulles, in an address to the General Assembly, made no specific montion of the Keshmir dispute or the SEATO pect, but did note that disputes should be referred to the security councll only after peacetul measures had been exhaustod. ${ }^{2}$ Dulle indirectly dofonded the paet by lmplying that Pakistan was under greater obligation to use peaceful mothods in solving the Kashinir deadloak. Pakistan could not, without violating the agreement and the UN Charter, enter into armed agression wth India over Irashir. Karechl, a signatory to the pact, agreed that:

The parties undertake, as set forth in tho Charter of the Unfted Nations, to settle any intornational disputes in which they nay bo invelved by peaceful meane in auch manner that international peace, security, and justice re not ondangered, and to rerrain in their international relations from the threat or use of farco in any menner inconsistent with the purposes of the United dations.

Pakletan, although thwarted in 1ts Keshmis objective,

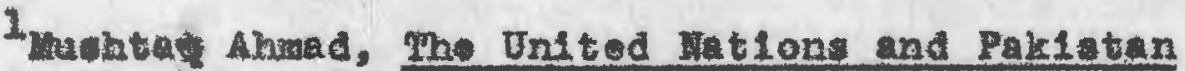
(Karachl: The Timod Prosa, 1955), p. 151.

20. H., G. A., Off. Ree., 9th session, 475th Plenary Heeting, 23 September 1954, P. 26 .

3 Wantag Ahmad, Tho United Hition and Pakistan (Karach1: The wimes Press, 1955), P. 150. 
ompatically defondod the pact into which 1 t had ontered. Prime Minister suhrawardy in 1956 proolalmed that his country would:

loyally adhere to the BHATO agresments and there is no question of our bualing out of any of our commlt tments or agreements. We wil loyelly stand by our alles,

\section{SWATO as V1ewed by India}

The signing of the SEATO pact procipitated groat foar and apprehenst on in India. Hehm, in apeaking before the Indian parliament, expressed great concern thet these SEATO powers would meddle In affairs that were none of their businoss. The internal frairs of India, and this inoluded Zashmir, whlch wa of vital domest1e concern to her, could never be interrupted by a "right to Intervene" by any of the SEATO mombers, ho sald. The Prime Miniater gaw a noed for India to do "somathlag" to thwart these pacts in Asia. H1. sountry could 112 afford, he declared, to walt unt1I It was absorbed by "evil forces" or other developwents which India did not like." The writer interprots Nehru's outlook on SFATO a pact the polnted ar foreed India Into an arms buili-up egalnst possiblo Pakistant threat of Invasion. SEATO made no great contribution townd stability In that area, ccording to Xriohna Menon, Indian delegate

IRak1eten Effale, 0etober 8, 1956, p. I.

India, Lok Sabha Secretarlat, Military Alliances, Excerpts from Pxime Minister Nehru's Speeches in Parliament, 1954-1956, (New Do1h1: Apri1, 1957), p.6. 
to the Unftod iations. He oxpocted that atability would be achleved through nelghborliness, non-interference, and by a world cooperating through the instrumentalities of the Untted Nations. Henon Implled that the SEATO pect was intervention by a forelgn power in Asian affeira.

Whon the SEATO Counoil discussed tho Kashmir Isaue in 1956, India was astounded, and saw Pakistan as using this organization to further its own demands on Kashis. Nohru, in a spoech to the Farliement, declared that this: ihe organization which it represents and its
reference to Kashir only means that
miltaryalizance is backing one country,
namely Pakistan, in its dispute with India.

Pakistan had joined these pacts, acording to Nehru, because of her hostility to India. Yet he absolved the Unfted states of any blame in this, by saying that the USA meant no wrong toward Inala; in fact, it probably did not ovon think of India in this conneotion. The Prime Minlster viewed these pacta as forces pushing the world in the wrong dipection.

To India, the SEATO poct and military ald to Pakistan had destroyed the very roots of the pleblaclte proposals in

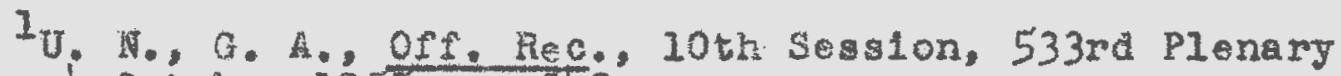
weoting, 4 oetober i955, p. 242 .

2India, Lok Sabha Secretarlat, Military Alliancos, Excorpts from Prime Minister Nohru's Spoecheg in Parliament, 1954-1956, (New DeIh1: April, 1957), p. 10. 
Kashmir. Nehru declared that he could not "talk with Pakistan on terms and facts that existed elght or nine years ago." I

\section{Karachi Views Kashmir Deadlock Vith Impatience}

Pakistan claimed that India was recolving more aconomic ald from the Unted States than Paklstan was obtaining under milltary agreements. This, declared Karaohi, enabled India to use its own economic resources to a much greater extent and to turn them into milltary oquipment and potential. A comparison of milltary strength between India and Pak1stan, 1t was pointed out, had no relevance to the 1ssue of holding a plebiscite in Kashmir. If the dispute continued, it would be diffleult for the government of Pakistan to restrain the Kashmirl refugeos in 1 ts country. The dispute once again had the ingredients of a grave threat to the peace of the world. ${ }^{2}$

Pakistan maintalned with spirit that American aid had not changed the issue at heart. Some writers agreed with rarachi on this. ${ }^{3}$ The Pakistani Forelgn Office saw

IIndia, Information Service, Kashmir, 1947-1956, Excerpts from Prime Minister Nehru's Speoches, (New Deini: United Press, old Secretariat, 1956), p. 42 .

${ }^{2}$ Pakistan, Pakistan Publications, Kashinir, PowderKeg of As1a, (Karach1: 1956).

3Joser Korbel, "New Hope for Kashm1r," Forelgn Poliey Bulletin, XXXIV (March 1, 1955), 3. 
no reason for India to cut off further negotlations on the 1ssue; In fact, Hohamad A11, Prime lnister of Pakfstan, declared in 1955 that Pakistan was prepared to explore and exhaust all possibilities for a peaceful settlement, but he warned that as time went on and the dispute continued unsolved, frustration and bitterness would seize the minds of the Kashmiris and Pakistani peoplo and they would turn to desperate mosures. He pledged Pakistan's very soul and existence to the deliverance of the Kashmirls from the Indian joke. 1

The 1ssue was not placed on the Security Coune11. agenda during 1956. In the General Assembly however, the Pak1stani delogate, Begum Ikramulluh, resurrected the issue and wanted the United Vations to sottle the dispute once and for all. She declared that the Security Council did not wish to offend India by making a flnal deciaion on the deadlock. 2

Pakistan felt justified in taking the military ald, demonstrating to the West its desire to thwart any possible Soviet aggression; or so Karachl informed the United States. The writer belleves that Pakistan looked upon these arms gains from the United States as a powerful bargalning agent in the Kashoir 1saue with India.

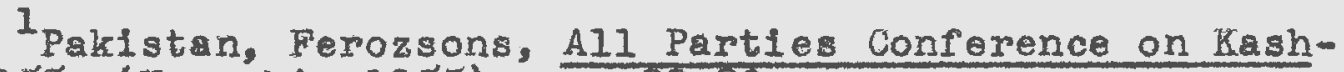
mir, 1955 (Karachi, 1955), pp. 22-23.

2. N., G. A., Off. Rec., 11th Session, 611th Plenary Heeting, 6 December 1956, p. 581 . 


$$
-55-
$$

Novertheless, Pakfatan's frustration over the unsolved Kashmir deadock was lowly reachlng very cruclal point. The year 1957 would see the dispute again before the Security Counc1l of the United Nations. 


\section{CHAPTER V}

RECENT DEVELOPUEMTS, 1957-1958

Apprehensiong over the Constituent Assembly

The lengthy period of llence on the Kashmir issue was finally broken in January 1957 when the securlty Council recelved a letter from the Prime Miniater of Paklatan. He aked the Counc1l to reconsider the IndianPaklstan dispute over Kashrir.1 Ee reminded the Coune1l that previously he had auggested a 500 man United rations force police the state of Kashmir. Hostilities would result if U. N. force were not sent immediately, ho added.2 Henry Cabot Lodge apparently supported Noon, for on January 16, 1957, he urged the Counc1l to establ1sh 1ts position on the issue a soon a posiblo. Lodge announced that if the constituent assembly in Indian-held frashir prociaimed 1ts intentions of determining the future of the state whout walting for U. N. pleblscite, then his government would be forced to reprove the activities of that body. He urged the Councll to assiat the diaputants Immodiately th respect to reaching an equitable settloment

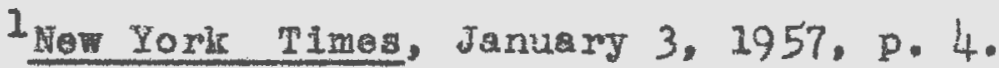
${ }^{2}$ Ib1d., January 15. 1957, p. 6. 
before India could ccept the new constitution from the assembly. 1

Jnfortunately, the Security Council did not act awifiy onough, notwithatanding the fact that Pakistan had the support of the United States at this particular phase of the problem. By January 21, 1957, the constituent assembly in Kashmir had promulgated new constitution for the state. It wes accepted by the Indian parliament on the same day. The legal bonds between Kashmir and India were now complete, and the unfted Nations was faced with falt accompl1. In addressing the Council on January 23 , Krishne ${ }^{2}$ non expressed the Indian attitude by indicating that his country had no intention of permitting a $U$. N. pleblocte in the state. Since Kashmir was now an integral part of the Indien Union, ho declared, it could never secede.2

Security Counc1l Resolution Reaffirms Its Stand on Plebiscite

Washington disagreod with this Indian stand. Delegate Lodge requested the Security Council to inform India that such a move on its part was 1llegal since the latter had consented to pleblscite in two UNCIP resolutions. The United States, United Kingdom, Australla, Colombia, and Cuba procoeded to offer a new draft rosolution.

${ }^{1}$ 0. N., s. C., off. Rec., 12th Ir., 761st Heot1ng, 16 January 1957, No. 761, p. 41.

${ }^{2}$ New York rimes, January 24,1957, p. 6. 
In substance, it declared that any past, present, or future activities of the constituent assembly in Indian-held Kashmir which attempted to decide the future affiliation of the state rould be inval1d. Inserted in the resolution was washington's insistence upon plobiscite to be held by the United vations. Lodge further rominded his listener. that India and Pakistan had agreed to this in 1948, 1949. and 1951, and this new Indian poliey had not changed the Council's declsion to hold plebisclte. In subsequent debate on the draft resolution the Indin delegate remarked that his government could not accept the recommendations of the Counc1l. Nevertheless, the Socurity Council adopted the American sponsored resolution by rote of 10 to 0 . The soviet delegate abstained from voting on this resolution. ${ }^{1}$

New Delhi Answers the Security Council

On January 26, 1957, the Indian government 1s sued official statements doclaring the accesion of Rashmir as irrevocable; furthormore, India would ignore any further Security Council resolutions on the Keshair dispute. The constituent assembly of the state was to be replaced by an elected logislative ssembly. An oxcerpt from the now Kashmir constitution 1liustrates the difficultios the securfty Counc1l would encounter in attempting to sever 
the as sociation:

The law rules out any amendment or bill, to make Kashair part of any other nation. 1

The State Department was persistent in urging a peacerul solution of the problew, but concrete suggestions were not exhiblted until one month later. There was some discussion in official Indian circies of the possibility of a solution based upon partition, but there were no attempts by the Council to investigate these reports. 2

\section{The Jarring Mission}

By the midile of Jebruary the Council was peady to suggest another offort toward atisfactory solution. The Unfted States, Unfted KIngdom, Australia, Cuba, and Colombla sponsored another jolnt draft resolution that aked for truce areoment, deralltarlzation, pleblscite, and the utilization of 0 . W. foree to pollce the voting procedures. The resolution sas vetoed by the Soviet Union, giving a its reason opposition to the use of U. U. force. Weshington fithdrew the 1tein on $U$. M. troops and the revisod dreft resolution was adopted by vote of 10 to 0 , the USSR abstaining. It ased the Socurlty Council Prosident, Gunnar V. Jarring of Sweden, to oxplore any and all

1 New York Times, January 26, 1957, p. 1. ${ }^{2}$ Ibld.. January 31,1757, p. 3. 
posslbilities of solution. If necessary he was to vistt the submcontinent for this purpose nd report back to the Council no lator than Apr11 15, 1957.1

The Jnitor States and the Jnited Kingdor had collaborated qut olosely or this rosolution. Its tone *a much milder than previous rosolutiona. In aging. Cunnar Jaxring to mediate for the Council, they selected man who had thorough unowledge and understanding of the trashin

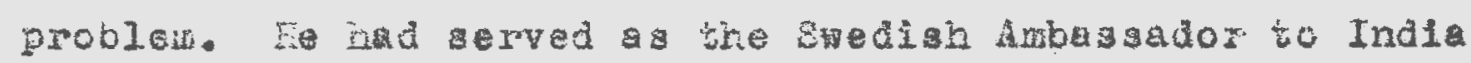
In 1940 and to Pakistan in 1952. Couglaered by his coporker in the Inited lations as "alplomatic gentlemen," he, If anyone, could help the two disputants in arriving at an imwediate solution. 2 hpparently, he know boforehand what the ouscome of his efforts would be, for in an intorview with Hew York Tires reporter, he sold he was not hopeful of any auccess of the mision. Fis methods of treating the subject were firgt to bring the two partios together to try and seek greements on a solution, and then to attempt to have it brought bofore the Intorrational Court of Justice if the first metrod fallea. 3

Tho Indian govarment was not partlould any concorned over the exigtence of the Jarring alssion. It hed ind ceted

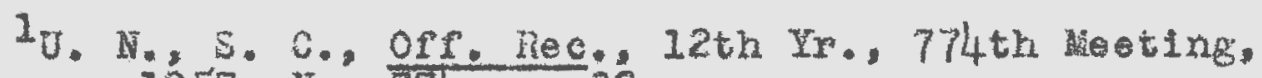
21 February 1957 , No: 774, p. 32 .

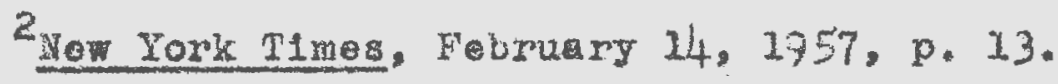

Ifla., February 16, 1957, p. 10. 
to the Council that any further resolutions on Kashmir would be 1gnored. In Eombay, Nehru asalled the BritiahAmerican stand on Kashair. He statod the only reason why Pakigtan had the support of these two powera was bocause of it membersip in the Bagdad pact. At later election rally at Kampur, he declared emphatically that his country would nover allow any power on earth to coerce her to change the Kashmir stand. I

Elections in Indian-Held Kashmir

In March 1957 elections were held in the Indian occupled area of Kashir. Some thirty-olght candidates were elocted to the leglalative asembly, and all wero members of the pro-Indian Kashoir National Conference Party. No oppostion parties were listed on the ballot. The question of plebisclte was not a campign issue. Authorities in the state saw to it that any opposition group ravoring plebisclte were technically erased from the election 11sts. Forty-four leading Kashmiris, all advocating a plebisoite, were held as polltical prisoners. Authorities clalmed this group followed an illegal polltical Ine which endangered the state.2

$1_{\text {NeW York Times, March } 5,1957, \text { p. } 3 .}$

${ }^{2}$ Ib1d., reh 6, 1957, p. 10. 
The Jarring Report

Gunnar Jarring submitted his report to the Securlty Council on April 30, 1957. He noted that both parties wanted to settle the problem but could find no baslo for agreement. HIs mission was unsuccessful. His recommendations included arbitration of questions involving the exact cease-fire Iine and the evacuation of troops from Kashmir. The arbitral body, according to Jarring, would later indicate to the parties what measures should be taken to arrive at a solution. Pakistan fell in line with his suggestions, but India did not think arbitration was appropriate to the Kashmir 1ssue. In a press dispatch to the New York IImos, Jarring regarded the case as closed. I

Washington and Karachi Continue Thelr Demands for a Pleblacito

Upon fallure of the Jerring mission, Pakistan and the United States ronewed their offorts for a plebiscite under U. N. ausplces. At a press conference in Washington, Secretary of State Dulles declared that since the Jarring negotiations were unsuccessful the security Counc1l decision to hold a plebiscite was binding on the partios. 2 Not only did Pakistan demand plebiacito but it asked for the unqualified support of the United States on the entlre Kashmir isgue.

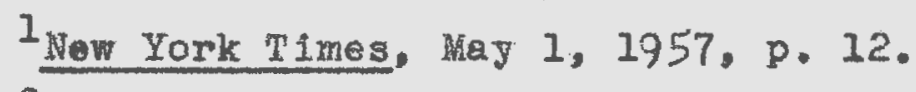

${ }^{2}$ J. S., Department of State pullet1n, "Statement by Secretary of State DuIIes," XXXVI TFebruary 25,1957 ), 306. 
Prime Minlster Suhrawardy was certain he could count on the United States to take pro-Pakistanl position in the Kashmir deadlock. He was confident that ith American pressure in the Councll and the Assembly, other nations could be mado to soe the justice of Pakistan's cause. I Karachl wanted the United States to repeat the stand it had taken in March 1957. The Pakistan Foreign Offle further asked that the United States discontinue ald or help to those nations, speciflcally India, whom Pakistan viewed as potent1al aggressors. Karachl sam Indla's rapid mllitary growth in 1956-1957 as indirectly based upon the sablo oconomic ald pouring in from the United States. ${ }^{2}$ India had been using this same argument agalnst Pakistan since 1954, but in relation to military and economic ald.

\section{The Resolution of December 1957}

The most recent attempt on the part of the United States to secure agroements loading to a solution was in the Securlty Councll in the lattor half of 1957. Viashington suggested that Dr. Frank P. Graham negotiate with India and Pakistan. The American representative, James Wadsworth, asked the Council to bo patient but persistent in continuing 1ts efforts to implement the previous UNCIP resolutions. Any further grements toward solution, he maintained, must

\footnotetext{
${ }^{1}$ Hew York Times, July 15, 1957, p. 3.

Pakiatan Naws Dizest, July 15,1957, p. 3.
} 
be based on these resolutions. I India and Paklstan had proviously agreed to truce agreerent, case-fire line, demilitarization, and plebiscite during the nogotiationg undertaken by the UNCIP In 1948-1950, and these resolutions, added wasworth, would be the groatest aids at solution. On Decembsr 2, 1957, the American recomendations ere cmbodied in resolution sponsored jolntly with the Unfted Kingdom. It requested Graham to act as mediator in tho Kashmir deadock. The resolution further requested both parties to refrain from issuing atatements that would aggravate the stuation. Before reporting back to the Counc11, Graham was asked to make all posslble suggestion and recommendations at solution. ${ }^{2}$ the American delegate aded that if progress could be ade on demilitarization issues, then possibly greements could be wad on other differences. 3

Pakiztan Seeks support

Through It Membership in the Bagdad Pact

Pakistan pleaded its case not only in the Unlted Nations, but in the Council sessions of the Bagda pact as we11. Prime unister Mran Noon made a frontal attack on

$I_{U}$. N., S. C., off. Rec., 12th Yr., 797th leeting, 25 october 1957. No. 797 , pp. 19-20.

2U. S., Department of State Bulletin, "The J. S. In the V. H.," XXXVII (December 23, 1957). 1016-1017. 3.J. H., S. C., Off. Rec., I2th Ir., Bo8th leeting, 2 Decomber 1957, No. 808, p. I1. 
the policies of the western nations for their large scale ald to so-called "neutralist" countries. Khan suggested that his country be equipped with atomic weapons. The United States and the United Kingdom were denounced for not supporting Pakistan on the Kashmir issue. For his country to remain with the fost, he announced, it must have substantial economic and milltary ald over and above that given to Ind 18.1

Karachi papers were extremely vocal over the lack of American support in Pakistan's demands on Kashmir. Tho editors of Dawn indicated that Noon's regime would soon fall if it did not obtain more economic assistance and miltary ald from the wost. 2 In a move that was hardly a surprise, Khan Noon informed his National Assembly that if the western allies falled his country on the rashmir dispute or stopped arms ald under pressure of India, his nation would break all pacts and seek other frlends. He concluded his speech by doclaring that Pakistan would undertak a thorough revision of Its Kashmir policy if Graham falled in this latest mission. 3

As of March 27, 1958, Frank P. Graham had not

I pakistan News Digest, Fobruary 15, 1958, p. 1 .

2Ib1d., p. 3. An editorial reproduced from Dawn, a dally newspaper published in Karechl, Paklstan, n.d. 3 Ib1d., 晾arch 15, 1958, p. 1 . 
submitted his report to the Security counc1l. The writer does not belleve that he will achleve any success in his mission.

In summerizing the recent attempts by the council to solve the deadlock, it should be noted that special emphasis was placed upon a plebisclte in Kashmir. The United States specifically indicated to India and Paklstan that they had agreed to a plebisclte in the oarlier UNCIP resolutions. The Jerring mission was to make use of these resolutions, and in order to implement them, Jarring urged the two parties to arbitrate all controversial lasues involving demilitarization of the state. Paxistan accepted his recommendations, Indla did not. The Jarring mission ended in rallure.

The Grahem mission followed in late 1957 and continued into 1958. There is little reason to expect that any agreements will result from Graham's negotiation with Indian and Pakistenf leaders.

In the interests of both India and Pakiatan the 1ssue should be settled because military expenditures are taking a great deal of neoded capltal from their economies. The Kashmir deadlock has contributed nothing toward the development and progress of the sub-continent. If arything, It has developed two opposing military forces, well equipped and trained for any emergency. The Kashmir issue has created massive arns supplies and equipment. Both countries should bo developing their agricultural and industrial resources to 


$$
-67-
$$

their fullest. With teeming millions to feed, and littlo food to distribute, Pakistan and India face tremendous problems in the years ahead. 
CHAPTER VI

CONCLUSIOHS

\author{
U. S. Polloy toward \\ the Accossion Instrument
}

Throughout the entire course of the investigation the writer has been unable to find any positive action which could be Interpreted as cceptanoe by Washington of the accession inatrument signed by the Maharaja of Kashmir and the Indian government. American delegates to the Unfted Nations made no reference to it in their discussions before the Securtty Counc1l or the General Assembiy. Ind I's entire argument was based on the legality of this agreement wioh the United States completely 1 gnored.

\title{
Peaceful lethods
}

as the First Key to Settlement

The United States did not sanction the use of violence In settling the Kashmir altuation. Washington did, however, suggest the use of $U$. N. fores to police the holding of a plebiscite if and wen it could be held. Pakiatan consented to this, but Indla strongly objected to the placing of forelgn troops on her soll. Conclilation, medlation, negotietion, arbitration, and justiciable settlement before the Internatlonal Court of Justlce were $s t 11$ other methods 
recomended by the State Department in solving the problem. Washington urged both partios to refrain from using force In their hagte to solve the deadlock. Thus, the first major key toward settlement was in continued use of pacific means of solution.

\section{The Second Key to Settlement}

Washington placed special emphas upon holding a free and lmpartial plobiscite in Kashmir. Just as Now Delhi rested its case on the accosalon agreement ajono, so the state Department based 1ts pollcy on second key to solution - upon plebiscite which would determine the future of the state. From 1948 to 1957 every proposal sponsored or approved by the United states included this essential 1tem. India orfiginally proposed the ploblscite as a solution and gave at least lip service to this means from 1947 to 1954. The claim by Indla that a change of circumstances altered the means of solution was put forth In May, 1954, and has been maintalned unt1l the present (1958). In justifylng 1ts reversal in rethods of solution, Nehru has clalmed that the Kaghmir issue had to be reconsldered due to the thrusting of military ald and forces 1nto Paklstan. Washington and Karachl deny that military ald has changed the issue of ploblscite.

\section{Charges of Aggression}

Ind1a has attemptod since 1948 to have the securlty 
Councli brand Pakistan as an agressor. In each 1nstance the American delegation falled to take any stand on this and abstainod from voting. The United States and other members of the Council would not condemn Pak1stan as the aggressor in Kashmir. U. N. mediators and comiasions were of course, not endowed with powers designed to establish responslbility or guilt in the deadlock.

\section{American Pollcles Were Not Neutrallst}

The United States could 111 afford to take definite side in disputes between the two powers and lose an lmportant potential ally. It chose to serve as a friendly, impartial arbiter and ran the risk of losing the good will of both. Patient listening and thoughtful suggestions of solution were two aspects of this pollcy. Paklstan viewed this American stand on Kashmir as definitely neutralist. New Delhi, however, viewed it as anti-Indian, washington ordered the American delegation to the United Nations to take part in all discussions on the issue. The evidence of active American particlpation toward solution of the problem can be seen in the nine resolutions sponsored by the United States alone or folntiy with other council members.

The Effect of Broad J. S. Pollcy upon the Kashmir Isaue 
major alms of which the first was stablity through adequate defense and internal security. Wasington believed that this could be best achieved by direct miltary aid to nations in this area. Pakistan appliod for this aid and rocelved $1 t$. India was offered quivalent ald and rejocted it. The arms bulld-up in Pakistan was an excuse used by India to deny a plobiscite in Kashmir and to hold on to the lioris share of the rea in aispute.

The second aim of this broad policy was assistance to each country in ereating conditions which would permit the economic and cultural development of the peoples in the area. Economic asistance was extended to both countries with more to India after 1956, much to the dismay of Karach1.

The core of this doctrine advocated the settlement of disputes through peaceful, equitable means both within and whout the United Nations. Broed polley oallod for the settlement of these problems in accordance with the morel principles and opinions of mankind.

\section{Prospects For The Future}

Fashington views the dispute a unchanged from its inception in 1948 to the present. New facts such as the milltary aid to Pakiatan and other alliances bave not altered the 1ssue, according to statements made by American delegates in the Security Council. Reports from the State Department indicate that a comon basis for agreement still 
oxists between India and Pakistan upon which they and the Councli can achievo sotilement. The United States values the friendahip of both countries. Although Pakistan has threatoned to use force to settle the isgue, the writer does not beileve that it rould ut1lize auch course of action.

Hostilities between India and Pakistan to settle the deadlock would be ghear folly. Both are conomially unable to undertake wartlo program. The only area upon which there lo similarity in polloy by the two contestante is their unqualified refusal to accept any form of partition. The State Department has nover suggested this as a solution. American policy has always been gulded by the desire of the Kashrirls, following the tradtional pollcy of gelf-determination. The allezma has beer that it cannot know these desires until a free plebisclte is held. The real mina of the peoplo cannot be acortained if foreign troops are their doorstop. Remove these troops, Insure the holding of free and impartial plebiscito, and the fact romalns that this will Do clear indication of the people's will.

If the plebiscite solution cannot be accomplished, what other course is there to take? American delegates to the Securlty Councli have stated that India and Pakistan do not want sottlement: 1

10. N., S. C., Off. Rec., 3rd Yr., 304th Moeting, 26 Meg 1948, pp. 20-21. 
Perhaps that is the case, for leaders in India and Pakistan know that if religion is to be the basis of nationality and Kashmir is the test case, then some forty million Huslims in Indis and fourteen million Hindus in Fast Pakistan imediately become semi-allens. Should war break out on the sub-continent the status of minorities in India and Pakistan would be deplorable; and the possibility of such a conflict depends largely on the Kashmir deadlock, its solution, and the method in which its future is determined.

In time of orisis the majority commity in the two countries would tend to consider the minority a potential "fifth column." Large scale migrations would rosult from war or even a plobigcite in favor of Pakistan. Migrations in the past were disastrous for both dominions. There is no guarantee that population movements in the future w1II be free from religlous and political rlots.

If the people of Keshmir abould decide in favor of Pakistan, the Indian concept of a secular state would be undermined. Possibly other Moslem areas in India would demand autonomy or association with Pakisten. Now Dolhi would never be ble to accept this.

Should the Kashmirls doclde agalast Pak1stan in a plebiscite, and favor an Incependent status, it would call into question the validity of the whole case of Pakistan's existence; for here the writer would see the first serious dental of the relighous atate.

If both chose to remin through the years on the 


$$
-74-
$$

cease-rlre line, the writer would have to admit that there is logic in the view thet noither side really wants final settlement. The greatest healor is time, and slowly tho status quo cones to be accepted. 


\section{BIBLIOGRA PHY}

\section{Books}

Ahmad, Hushtag. The United Nations and Pakistan. Karach1: The Times Press, 1955.

Girdwood, Lord. India and Pakistan. New York: F. A. Praeger, 1954.

Eowles, Chester B. Ambassador's Report. New York: Harper and Brothers, 1954 .

Erecher, Michael. Struggle for Kashmir. New York: Oxford University Press, 1953.

Eagleton, clyde. International Government. New York: Ronald Press, 1957.

Korbel, Josef. Danger in Kashmir. Princeton, New Jersey: Princeton University Press, 1954.

Kothar1, Shartilal. India's Emerging Forelgn Pollcles. Bombay: Vora and Company, 1951.

\section{Government Publications}

India, Information Serv1ce. Kashmir, 1947-1956, Excerpts from Prime Minister Nehru's Speeches. New Delhi: United Press, old Secretarlat, 1956.

- Kaghmir, Factual Survey. New Delhi: United Press, 0ld Secretariat, 1956.

Ind1a, Lok Sabha Secretariat. Ml1tary Alliances, Excerpts from Prime Minister Nehru's Speeches in Parliament, 1954-1956. New Delh1: Lok Sabha Secretariat, 1957.

Pakistan, Ferozsons. All Parties Conference on Kashmir. Karachi: 1955.

Paklstan, Pakistan Publications. Kashmir, Powder-Keg of As18. Karach1: 1956. 
Articles and Perlodioals

Eowles, Chester B. "Partnership which Mast Hot Fa11," Vital Speeches, XVIII (March 1, 1952), 304-308.

Howard, harry N. "the Development of U.S. Polloy in the Near Eest, South Asla, and Africa, 1951-1952," Department of State Bulletin, XXVII (November, 1952). $891-898$.

India, linistry of External Affa1ra. Foreign Affalrs Record, I (July, 1955), 153.

Korbe1, Josef. "New Hope for Kashm1r," Forelgn Pollcy Bulletin, XXXIV (Miarch 1, 1955), 89-90.

lehta, G. L. "India in world Affelrs," Vital Speeches, XXI (JuIy 1, 1955), 1322-25.

"Should U. S. G1ve Mllitary Ald to Paklstan?," Forelgn Policy Bulletin, XXXIII (Fobruary 15, 1954), 4 .

"Truth and Consequences in World Affairs," Foreign Polley Bullet1n, XXXIII (January 15, 1954), 6-7.

U. S., Department of State. "Fleet Adm., Named as Kashmir Pleblscite Administrator," Department of State Bullet1n, XX (March, 1949), 419.

- "Department Encoureged by India-Pakistan Talks," Department of state Bulletin, XXII (Apr11, 1950), 631.

- "Statementa by Secretary of State Dulles," Department of State BuIletin, XXXVI (Fobruary, 1957), $300-306$.

- "The Problem of Security," Department of State Eulletin, XXX (March, 1955), 447.

- "The U. S. In the U. H.," Department of State Bulletin, XXVII (December, 1952), 1042-43.

- "The U. S. In the U. H.," Department of State Bullet1n, XXXVII (December, 1957), 1011-17.

- "The U. S. - Pak1stan siutual Defenso Assistance Agroement," Department of State Bulletin, XXX (June, 1954), 850-51.

- "V. N. Action Reviewed," Department of State Eulletin, XXI (October, 1949), 654 . 
- "U. S. Views on Prospects for Settling Kashmix Controversy," Department of State Eulletin, XXVII (December, 1952), 1030-31.

\section{Newspapers}

Pakistan Affairs. 1956-1958.

Pak1stan News D1gest. 1957-1958.

New York Times. 1947-1957.

\section{Public Documents}

United Nations, General Assembly. Offlcial Records. 3rd Session, 1948 - 5th Session, 1950.

- 7th Session, 1952.

- 9th Session, 1954 - 11th Session, 1956.

United Nations, Security Council. Offlcial Records. 3rd $\mathrm{Y}_{\mathrm{r} .,} 1948-7_{\text {th }} \mathrm{Yr}_{\mathrm{r}}, 1952$. . 12th Yr., 1957. 